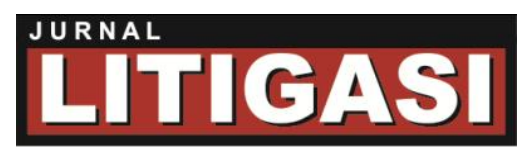

Available online at: http://ejournal.unpas.ac.id/index.php/litigasi

Litigasi, Vol. 17(1), 2016, 3167-3220

DOI: http://dx.doi.org/10.23969/litigasi.v17i1.48

\title{
KEBIJAKAN PEMBERIAN HAK REMISI NARAPIDANA KASUS KORUPSI
}

\author{
Elizabeth Ghozali
}

Fakultas Hukum Universitas Katolik St. Thomas.S.U. Medan, Jl. Setia Budi No. 479 F Medan, Hp: 081375665559,Email: beth ghoz@yahoo.co.id

\begin{abstract}
ABSTRAK
Hak remisi narapidana bukan merupakan hak yang bersifat inalienable rights (yang tidak dapat dihapus atau dicabut). Hak remisi adalah hak yang terbatas, yakni dibatasi oleh syarat dan tata cara tertentu. Namun, pembatasan syarat dan tata cara tersebut tidak dapat dilakukan secara direktif melalui PP Nomor 99 Tahun 2012, karena dalam UU Pemasyarakatan, hak remisi adalah hak setiap narapidana tanpa ada pembedaan berdasarkan kualifikasi tindak pidana yang dilakukan. Oleh karena itu, agar dalam penegakan hukum pemberian remisi kepada narapidana kasus korupsi jangan sampai melanggar hukum, perlu dilakukan penyesuaian (harmonisasi) terhadap UU Pemasyarakatan.
\end{abstract}

Kata Kunci: Hak Asasi Manusia, Remisi, Korupsi.

\begin{abstract}
Remission rights is not inalienable rights (which can not be removed or revoked). Remission is limited rights, by the specific requirements and procedures. However, restrictions on the terms and procedures can not be done through Government Regulation No. 99 of 2012 directive, because according the Corrections Act, remission is the rights of every prisoner without any distinction based on qualifications criminal offense committed. Therefore, in order for remissions does not irregulatities, the determination of restrictions on the remission's rights of corruption's prisoners needs to adjustments (harmonization) of the Corrections Act.
\end{abstract}

Keywords: Human Rights, Remission, Corruption.

Copyright @ 2016, LITIGASI, p-ISSN: 0853-7100; e-ISSN: 2442-2274 
Available online at: http://ejournal.unpas.ac.id/index.php/litigasi

Litigasi, Vol. 17(1), 2016, 3167-3220

DOI: http://dx.doi.org/10.23969/litigasi.v17i1.48

\section{PENDAHULUAN}

Pemberian remisi biasanya diumumkan secara nasional

bersamaan dengan peringatan hari Kemerdekaan Republik Indonesia dan hari-hari besar keagamaan. Remisi kembali ramai dibicarakan setelah Menteri Hukum dan Hak Asasi Manusia, Yasonna H. Laoly mengemukakan ide untuk melakukan perubahan terhadap Peraturan Pemerintah (PP) Nomor 99 Tahun 2012, yang selama ini memperketat peluang narapidana kasus korupsi untuk memperoleh remisi. Menteri Hukum dan Hak Asasi Manusia tidak sepakat dengan PP Nomor 99 Tahun 2012, alasannya bahwa seburuk-buruknya narapidana kasus korupsi, mereka tetap harus diberikan haknya untuk mendapatkan keringanan hukuman seperti narapidana kasus lainnya.

Kebijakan berkaitan dengan pemberian remisi bagi narapidana kasus korupsi selalu menimbulkan polemik, karena: (Berlian Simarmata, 2011 : 516 517).

1) Ketidakpahaman perubahan paradigma penjara menjadi lembaga pemasyarakatan, tujuan pemidanaan bukan lagi pembalasan melainkan pembinaan (pemasyarakatan).

2) Tidak bekerjanya sub-sub sistem peradilan pidana dengan baik. Rasa keadilan masyarakat menjadi terusik ketika seorang koruptor yang mengambil uang negara (rakyat) miliaran atau puluhan bahkan ratusan milyar, secara riil hanya menjalani dua hingga tiga tahun pidana penjaranya di lembaga pemasyarakatan.

Copyright $\odot$ 2016, LITIGASI, p-ISSN: 0853-7100; e-ISSN: 2442-2274 
Available online at: http://ejournal.unpas.ac.id/index.php/litigasi

Litigasi, Vol. 17(1), 2016, 3167-3220

DOI: http://dx.doi.org/10.23969/litigasi.v17i1.48

3) Proses penilaian terhadap narapidana yang berhak untuk memperoleh remisi.

Kurangnya personil dan fasilitas pembinaan di lembaga pemasyarakatan akan berakibat pada kesulitan penilaian, dan akibatnya kepala lembaga pemasyarakatan cenderung mengambil jalan pintas untuk selalu memberi dan seolah-olah menjadi kewajibannya untuk memberikan (hak) remisi kepada narapidana. Di samping itu, sulit untuk membantah bahwa remisi itu sering dibarengi dengan pemberian suatu 'harga' tertentu. Keadaan ini akan mudah dimanfaatkan oleh orang yang memiliki uang yang banyak, seperti para koruptor untuk memperoleh remisi yang maksimum. Khusus bagi narapidana koruptor, perilaku untuk memberikan uang di bawah tangan guna memperoleh remisi yang maksimum didukung oleh belum adanya kebijakan dan aturan untuk memiskinkan para koruptor. Perilaku narapidana-narapidana koruptor ini bertolak belakang dengan masyarakat kecil dan lemah dari segi ekonomi, yang sulit untuk memperoleh remisi atau remisi maksimum.

Selain itu, juga ada sejumlah sinyalemen pengistimewaan proses pro justitia maupun perlakuan diskriminatif pengistimewaan terhadap para calon tersangka dan tersangka kasus korupsi lainya (Saldi Isra, 2015).

Beberapa kasus yang dapat dikemukakan tentang perlakuan istimewa tersebut, adalah :

1) Artaliya Suryani alias Ayin, narapidana perkara suap terhadap jaksa Urip Tri Gunawan.

Copyright @ C 2016, LITIGASI, p-ISSN: 0853-7100; e-ISSN: 2442-2274 
Available online at: http://ejournal.unpas.ac.id/index.php/litigasi

Litigasi, Vol. 17(1), 2016, 3167-3220

DOI: http://dx.doi.org/10.23969/litigasi.v17i1.48

Berdasarkan nota dinas Direktur Jenderal Pemasyarakatan nomor: 116/X/2010 kepada Menteri Hukum dan HAM tanggal 26 Oktober 2010 dinyatakan Ayin tak berhak mendapatkan Remisi Umum 2010, karena dari hasil inspeksi mendadak (Sidak) Satuan Tugas Pemberantasan Mafia Hukum di Rutan Pondok Bambu pada tanggal 10 Januari 2010, telah ditemukan adanya pemberian fasilitas berlebihan yang diberikan kepada narapidana atas nama Artalyta Suryani oleh petugas Rutan. Pemberian fasilitas tersebut terjadi karena adanya 'kerja sama' antara narapidana Artalyta Suryani dengan petugas. Di nota tersebut juga tertulis, bahwa baik narapidana Artalyta Suryani maupun petugas menyadari bahwa tindakan yang mereka lakukan tersebut merupakan bentuk pelanggaran tata tertib dan disiplin. Namun, Ayin tetap diusulkan untuk memperoleh pembinaan lanjutan berupa Pembebasan Bersyarat dan usul tersebut disetujui, sehingga Ayin kemudian mendapatkan remisi selama 2 bulan 20 hari. Sebelumnya, Ayin juga telah mendapatkan remisi pada Hari Waisak 2010 selama 1 (satu) bulan (http://nasional.kompas.com).

2) Urip Tri Gunawan, jaksa yang menerima suap dari Artalyta Suryani.

Urip divonis 20 tahun terhitung sejak masa penahanan yakni Maret 2008. Pada 2010, Urip sudah menerima remisi khusus Natal dan remisi umum pada 2011. Dalam keterangan pers, pejabat Lembaga Pemasyarakatan Cipinang menyatakan Urip berhak atas remisi karena telah menjalani 6 (enam) bulan masa pidana. Padahal Urip sebagai narapidana pelaku tindak

Copyright @ 2016 , LITIGASI, p-ISSN: 0853-7100; e-ISSN: 2442-2274 
Available online at: http://ejournal.unpas.ac.id/index.php/litigasi

Litigasi, Vol. 17(1), 2016, 3167-3220

DOI: http://dx.doi.org/10.23969/litigasi.v17i1.48

pidana korupsi seharusnya mendapat remisi setelah menjalani 1/3 (satu per tiga) masa pidana yakni pada 2014 (http://www.unisosdem.org).

3) Anggodo Widjojo, terpidana kasus korupsi percobaan menyuap penyidik dan pimpinan $K P K$.

Berdasarkan putusan Mahkamah Agung pada tanggal 3-3-2011, Anggodo dikenakan pidana penjara menjadi 10 tahun penjara dan denda $R p$. 250 juta. Peninjauan Kembali terpidana Anggodo ditolak oleh Mahkamah Agung pada tanggal 10-12-2012, sehingga hukuman tetap sesuai kasasi. Jadi sesuai putusan pengadilan, hukuman yang harus dijalani terpidana Anggodo seharusnya 10 tahun penjara. Namun dalam pelaksanaannya, sejak ditahan pada Januari 2010, Anggodo baru menjalani 4 tahun lebih beberapa bulan masa penjara, berarti belum ada separuh masa hukuman. Namun, Lembaga Pemasyarakatan Sukamiskin Bandung tempat Anggodo dipenjara telah mengajukan Pembebasan Bersyarat terhadap Anggodo, karena Anggodo telah menjalani 2/3 masa tahanan dan sudah membayar dendanya ( $R p 150$ juta), dia juga berkelakuan baik dan telah menjalani semua program di lembaga pemasyarakatan."

Bagaimana dikatakan Anggodo sudah menjalani 2/3 masa hukuman? Ternyata Anggodo telah mendapat remisi atau pengurangan hukuman yang fantastis, yakni 29 bulan 10 hari. Jumlah tersebut merupakan akumulasi dari remisi umum yang diberikan setiap 17 Agustus, remisi khusus pada hari besar keagamaan, dan remisi dari menteri kesehatan yang diberikan pada setiap

Copyright @ C 2016, LITIGASI, p-ISSN: 0853-7100; e-ISSN: 2442-2274 
Available online at: http://ejournal.unpas.ac.id/index.php/litigasi

Litigasi, Vol. 17(1), 2016, 3167-3220

DOI: http://dx.doi.org/10.23969/litigasi.v17i1.48

peringatan hari kesehatan dunia. Anggodo mendapat remisi kesehatan karena dianggap menderita sakit permanen. Jumlah remisi ini setara dengan separuh lebih dari masa hukuman yang telah dijalani Anggodo yang baru 4 tahun lebih beberapa bulan. Jika Pembebasan Bersyarat disetujui, maka terpidana korupsi Anggodo akan melenggang bebas dari penjara walau belum menjalani separuh dari masa hukumannya. Padahal pemberian remisi kepada Anggodo, masih mengacu pada syarat yang ditetapkan dalam PP Nomor 28 Tahun 2006, yakni berkelakuan baik dan telah menjalani 1/3 (satu pertiga) masa pidananya. Berarti remisi pertama baru dapat diperolehnya pada tahun 2013 dan itu pun jumlahnya tidak lebih dari 2 (dua) bulan. Oleh karena itu, sangat aneh jika Anggodo dapat memperoleh remisi sampai 29 bulan 10 hari (Forum Keadilan, $2014: 24$ ).

Fakta-fakta yang terbentang tersebut, menyebabkan munculnya penolakan dari berbagai kalangan yang concern terhadap pemberantasan korupsi, ketika para narapidana kasus korupsi berupaya mempersingkat masa pemidanaan melalui "fasilitas" remisi. Desakan melakukan pengetatan persyaratan pemberian remisi terhadap narapidana kasus korupsi juga didorong oleh sejumlah bentangan empirik bahwa lembaga pemasyarakatan lebih banyak menjadi tempat persinggahan sementara bagi koruptor. Karena itu langkah pengetatan harus ditempatkan sebagai point of no return dalam agenda pemberantasan korupsi.

Copyright @ C 2016, LITIGASI, p-ISSN: 0853-7100; e-ISSN: 2442-2274 
Available online at: http://ejournal.unpas.ac.id/index.php/litigasi

Litigasi, Vol. 17(1), 2016, 3167-3220

DOI: http://dx.doi.org/10.23969/litigasi.v17i1.48

Pada saat dilakukan pengetatan persyaratan pemberian remisi bagi narapidana kasus korupsi oleh Presiden SBY pada tahun-tahun terakhir pemerintahannya melalui PP Nomor 99 Tahun 2012, juga menimbulkan kontroversi pada saat itu. Argumennya bahwa remisi merupakan hak warga binaan sesuai namanya, adalah hak asasi yang masih tersisa pada setiap warga binaan sebagaimana telah diatur dalam Pasal 14 ayat (1) huruf i Undang-Undang Nomor 12 Tahun 1995 tentang Pemasyarakatan (UU Pemasyarakatan), yang telah sejalan dengan ketentuan Standard Minimum Rules for the Treatment of Offenders $P B B$ tahun 1955, bahkan telah sejalan dengan ketentuan $B A B X A$ UUD 1945.

Jadi, mempertentangkan antara hak asasi manusia dalam rangka pembinaan dengan efek jera, yang menjadi bagian dari pro dan kontra pengetatan persyaratan remisi tersebut. Remisi dipandang sebagai hak dari narapidana pelaku tindak pidana korupsi dan sejalan dengan filosofi pelaksanaan pidana penjara yang memasyarakatkan kembali terpidana dengan melakukan pembinaan, sehingga jika narapidana telah memenuhi persyaratan yang ditentukan dalam peraturan perundang-undangan tanpa terkecuali termasuk narapidana kasus tindak pidana korupsi (Nyoman Serikat Putra Jaya, 2011 : 2). Menurut Romli Atmasasmita, korupsi memang termasuk kejahatan yang harus ditangani secara luar biasa baik dalam tingkat penyidikan maupun pada tingkat pemeriksaan di muka pengadilan. Namun seketika putusan pengadilan telah dijatuhkan dan mengubah status terdakwa menjadi terpidana apalagi setelah memperoleh putusan pengadilan yang

Copyright @ C 2016, LITIGASI, p-ISSN: 0853-7100; e-ISSN: 2442-2274 
Available online at: http://ejournal.unpas.ac.id/index.php/litigasi

Litigasi, Vol. 17(1), 2016, 3167-3220

DOI: http://dx.doi.org/10.23969/litigasi.v17i1.48

tetap maka tidak ada lagi perlakuan-perlakuan yang luar biasa terhadap narapidana kasus korupsi. Karena, keberadaan mereka di dalam lembaga pemasyarakatan bukan termasuk ranah penegakan hukum (law enforcement) lagi, melainkan ranah pembinaan narapidana (treatment). Atas dasar pembedaan tersebut maka sejak lama telah diakui perbedaan yang signifikan antara penghukuman (punishment) di satu sisi dan pembinaan narapidana (treatment of prisoners) di sisi lain (Romli Atmasasmita, 2011).

Berkaitan dengan pembedaan antara penghukuman dan pembinaan, Andi Hamzah pada saat didengar keterangannya sebagai ahli dalam persidangan di Mahkamah Konstitusi, dengan merujuk pada pendapat J. M. van Bemmelen, menyatakan bahwa ruang lingkup acara pidana mencakup 7 (tujuh) tahap, yaitu:

(1) Mencari kebenaran;

(2) Mencari pembuat (tindak pidana);

(3) Menangkap pembuat dan kalau perlu menahannya;

(4) Mengumpulkan bahan-bahan bukti untuk diajukan ke pengadilan;

(5) Pengambilan putusan oleh hakim;

(6) Upaya hukum untuk melawan putusan hakim tersebut; dan

(7) Pelaksanaan putusan hakim (eksekusi).

Dengan eksekusi yang dilakukan oleh jaksa, maka berakhirlah proses (due process) acara pidana. Selanjutnya, pembinaan narapidana tidak lagi berada dalam ranah kekuasaan kehakiman (yudikatif), tetapi beralih ke dalam ranah kekuasaan eksekutif, yang dalam hal ini dilaksanakan oleh lembaga 
Available online at: http://ejournal.unpas.ac.id/index.php/litigasi

Litigasi, Vol. 17(1), 2016, 3167-3220

DOI: http://dx.doi.org/10.23969/litigasi.v17i1.48

pemasyarakatan yang berada di bawah Departemen Hukum dan HAM (sekarang Kementerian Hukum dan HAM). Remisi diberikan kepada narapidana yang telah dijatuhi hukuman berdasarkan putusan hakim yang telah mempunyai kekuatan hukum tetap dan telah menjalani pidana yang dijatuhkan untuk periode tertentu, serta harus dipenuhi syarat-syarat tertentu oleh narapidana yang bersangkutan (Putusan MKRI Nomor: 022/PUU-III/2005 : 37 - 38).

Namun di sisi lain ada pandangan dalam masyarakat bahwa pemberian remisi bagi narapidana kasus korupsi dipandang sebagai bentuk pengingkaran terhadap rasa keadilan bagi masyarakat. Lamanya masa pidana yang dijatuhkan oleh pengadilan serta lamanya pidana yang dijalani oleh terpidana korupsi dipandang tidak sebanding dengan kerugian yang diakibatkan perilaku korupsi yang ditanggung masyarakat Indonesia (Nyoman Serikat Putra Jaya, 2011 : 2).

Berbagai pandangan muncul di masyarakat terkait kebijakan pemerintah yang melakukan pengetatan terhadap pemberian remisi bagi narapidana kasus korupsi, mengingat kejahatan korupsi merupakan the seriousness of problem dan juga "...threat to the suistainable development of people". Selain itu, Dalam A Human Rights Approach to Prison Management terbitan International Center for Prison Studies dijelaskan bahwa "Narapidana Juga Manusia". Karena narapidana juga manusia, maka narapidana juga memiliki hak asasi manusia, seberat apa pun kejahatan yang telah diperbuatnya. Apalagi telah ada peraturan perundangan yang mengatur tentang remisi, pada hakekatnya remisi merupakan hak narapidana (Pasal 14 ayat (1) huruf i UU Pemasyarakatan) tanpa embel-embel

Copyright @ C 2016, LITIGASI, p-ISSN: 0853-7100; e-ISSN: 2442-2274 
Available online at: http://ejournal.unpas.ac.id/index.php/litigasi

Litigasi, Vol. 17(1), 2016, 3167-3220

DOI: http://dx.doi.org/10.23969/litigasi.v17i1.48

koruptor. Jadi polemik pengetatan syarat hak remisi narapidana kasus korupsi adalah diantara hak asasi narapidana dan masyarakat yang terkena dampak korupsi dengan efek jera dari sistem pemidanaan.

Berdasarkan uraian di atas, maka yang menjadi pertanyaan mendasarnya adalah, apakah pengetatan syarat pemberian remisi bagi narapidana kasus korupsi melanggar hak asasi narapidana? dan bagaimanakah kebijakan pemberian remisi di masa yang akan datang bagi narapidana kasus korupsi?

\section{PEMBAHASAN}

\section{Hak Asasi Manusia Dalam Konstitusi Negara}

Perlindungan hak asasi manusia mutlak diberikan kepada setiap individu tanpa harus melihat dan membedakan latar belakangnya. Pengakuan hak asasi manusia memperoleh legitimasinya secara internasional melalui pengesahan Perserikatan Bangsa-Bangsa (PBB) terhadap The Universal Declaration of Human Rights (Deklarasi Umum Hak Asasi Manusia/DUHAM) tanggal 10 Desember 1948. Indonesia sebagai bagian dari masyarakat dunia patut menghormati hak asasi manusia yang termaktub dalam DUHAM (Konsideran Tap MPR Nomor XVII/MPR/1998; huruf b) dan mempunyai tanggung jawab untuk menghormati DUHAM serta instrumen internasional lainnya mengenai HAM (Konsideran Tap MPR Nomor XVII/MPR/1998; huruf c).

Oleh karena itu, Indonesia ikut meratifikasi serta mengadopsi berbagai aturan mengenai hak asasi manusia yang berasal dari hukum internasional.

Copyright $\odot$ 2016, LITIGASI, p-ISSN: 0853-7100; e-ISSN: 2442-2274 
Available online at: http://ejournal.unpas.ac.id/index.php/litigasi

Litigasi, Vol. 17(1), 2016, 3167-3220

DOI: http://dx.doi.org/10.23969/litigasi.v17i1.48

Konstitusi Indonesia secara prinsip mengadopsi semangat bahwa hak asasi manusia memiliki nilai-nilai dan prinsip-prinsip yang berlaku universal (Adnan Buyung Nasution, 2011 : 7). Perubahan besar pengaturan hak asasi manusia dalam UUD 1945 terjadi dalam Perubahan Kedua UUD 1945 pada tahun 2000. Aturan hak asasi manusia secara khusus dicantumkan dalam BAB XA tentang Hak Asasi Manusia yang terdiri dari sepuluh pasal, yakni Pasal 28 A sampai dengan 28 J. Sepuluh pasal tersebut terdiri dari 26 ayat.

Dari 26 ayat tersebut, 18 diantaranya memuat ketentuan tentang hak individu. Hak yang bersifat individual adalah hak setiap individu manusia. Hak ini dalam konstitusi dirumuskan dengan kalimat "setiap orang". Setiap orang berarti siapa saja. Tidak pandang apakah warga negara Indonesia atau bukan. Sepanjang dia manusia dan hidup di Indonesia, maka UUD 1945 mengakui dan menjamin keberadaan dan kelangsungan hak asasinya. Rumusan serupa juga ditemukan dalam DUHAM dan berbagai konvensi utama di bidang hak asasi manusia. Hal demikian menunjukkan bahwa hak (individu) yang diatur dalam UUD 1945 sama dengan hak yang diatur dan dipersepsikan oleh dunia (Saldi Isra, 2014 : 414).

Konstitusi Indonesia di dalam menjamin hak-hak tersebut menyatakan bahwa, ada sejumlah hak yang tidak dapat dikurangi dalam keadaan apapun. Hak tersebut merupakan hak asasi minimal yang tidak boleh dilanggar dalam kondisi apapun (non derogable) (Todung Mulya Lubis, 2005 : 190). Hak tersebut ditetapkan dalam Pasal 28 I ayat (1) UUD 1945, yakni: (1) hak 
untuk hidup, (2) hak untuk tidak disiksa, (3) hak kemerdekaan pikiran dan hati nurani, (4) hak beragama, (5) hak untuk tidak diperbudak, (6) hak untuk diakui sebagai pribadi di hadapan hukum, dan (7) hak untuk tidak dituntut atas dasar hukum yang berlaku surut. Dapat diintrepretasikan bahwa hak-hak yang tidak disebutkan dalam Pasal 28 I UUD 1945 adalah hak-hak yang dapat dikurangi (derogable rights) (Sefriani, $2012: 4$ ).

Selain itu, di dalam UUD 1945 juga terdapat ketentuan terkait kewajiban dalam konteks hak asasi manusia. Menurut Saldi Isra (Saldi Isra, 2014 : 416), ada dua pasal yang mengaturnya, yakni:

(1) Pasal 28I ayat (4) UUD 1945 yang menyatakan: "Perlindungan, pemajuan, penegakan, dan pemenuhan hak asasi manusia adalah tanggung jawab negara, terutama pemerintah".

(2) Pasal 28 J ayat (1) UUD 1945 menyatakan "Setiap orang wajib menghormati hak asasi manusia orang lain dalam tertib kehidupan bermasyarakat, berbangsa, dan bernegara".

Hal yang diatur dalam Pasal 28I ayat (4) UUD 1945 merupakan kewajiban negara. Oleh karena itu, negara terutama pemerintah wajib melaksanakannya. Ada empat kewajiban yang dibebankan kepada negara terkait HAM, yaitu: melindungi, memajukan, menegakkan dan memenuhi hak asasi manusia. Adapun yang diatur dalam Pasal 28 J ayat (1) UUD 1945 adalah kewajiban individu terkait HAM. Berbeda dengan negara, individu hanya dibebani kewajiban untuk menghormati HAM orang lain (Saldi Isra, $2014: 417$ ).

Copyright $\odot$ 2016, LITIGASI, p-ISSN: 0853-7100; e-ISSN: 2442-2274 
Available online at: http://ejournal.unpas.ac.id/index.php/litigasi

Litigasi, Vol. 17(1), 2016, 3167-3220

DOI: http://dx.doi.org/10.23969/litigasi.v17i1.48

Pengaturan lebih lanjut terkait jaminan pelaksanaan HAM terdapat dalam Pasal 28I ayat (5) UUD 1945, yang menyatakan:

"Untuk menegakkan dan melindungi hak asasi manusia dengan prinsip negara hukum yang demokratis, maka pelaksanaan hak asasi manusia dijamin, diatur, dan dituangkan dalam peraturan perundang-undangan".

Ketentuan tersebut memberi mandat kepada peraturan perundang-undangan untuk mengatur pelaksanaan hak asasi manusia. Tujuan pengaturan tersebut agar pelaksanaan hak asasi manusia dilakukan sesuai dengan prinsip negara hukum yang demokratis. Asas-asas hukum yang membatasi pengaturan oleh negara tersebut diantaranya adalah asas legalitas, asas negara hukum, asas untuk menghormati martabat kemanusiaan, asas persamaan dan nondiskriminatif, asas hukum tidak berlaku surut, asas ne bis in idem dan asas proporsionalitas .

Meskipun konstitusi negara mengatur dan menjamin hak asasi manusia setiap orang atau setiap individu, namun menjalankan hak asasi manusia yang dimiliki oleh setiap orang atau setiap individu tersebut, bukan tanpa batas. Hak seseorang hanya bebas dimiliki dan dilaksanakan sepanjang pelaksanaannya tidak melanggar hak dan kebebasan orang lain (Pasal 28) Ayat (2) UUD 1945). Pembatasan hak sebagaimana dimaksud Pasal 28j Ayat (2) merupakan otoritas negara (Saldi Isra, 2014 : 418). Perspektif umum mengatakan bahwa pembatasan hanya dapat dilakukan terhadap hak-hak yang

Copyright @ 9 2016, LITIGASI, p-ISSN: 0853-7100; e-ISSN: 2442-2274 
Available online at: http://ejournal.unpas.ac.id/index.php/litigasi

Litigasi, Vol. 17(1), 2016, 3167-3220

DOI: http://dx.doi.org/10.23969/litigasi.v17i1.48

masuk kategori hak yang dapat dikurangi (derogable rights) dan tidak berlaku bagi hak yang tidak dapat dikurangi (non-derogable rights).

Sebagaimana konstitusi memberi mandat kepada peraturan perundangundangan untuk mengatur pelaksanaan HAM, maka dalam hal pembatasan pemenuhan HAM, juga harus dilakukan berdasarkan hukum dan ditetapkan dengan undang-undang. Beberapa ketentuan yang mengatur mengenai syarat dan alasan pembatasan pemenuhan HAM, yaitu:

1) Pasal 29 ayat (2) DUHAM menyatakan bahwa pembatasan pemenuhan HAM hanya dapat dilakukan berdasarkan beberapa alasan berikut:

(1) dilakukan berdasarkan hukum;

(2) untuk menjamin pengakuan serta penghormatan yang layak bagi hakhak dan kebebasan orang lain;

(3) untuk memenuhi syarat-syarat yang benar dari kesusilaan; dan

(4) demi tata tertib umum dalam suatu masyarakat demokrasi.

2) Pasal 28j ayat (2) UUD 1945, pembatasan pemenuhan hak asasi manusia dapat dilakukan dengan alasan berikut:

(1) ditetapkan dengan undang-undang;

(2) menjamin pengakuan serta penghormatan atas hak dan kebebasan orang lain;

(3) memenuhi tuntutan yang adil sesuai dengan pertimbangan moral, nilainilai agama, keamanan, dan ketertiban umum dalam suatu masyarakat demokratis.

3) Pasal 12 ayat (3) International Covenant on Civil and Political Rights (ICCPR / Konvenan Internasional tentang Hak-hak Sipil dan Politik) menyatakan bahwa pembatasan pemenuhan hak asasi manusia hanya dapat dilakukan dengan alasan berikut:

Copyright @ C 2016, LITIGASI, p-ISSN: 0853-7100; e-ISSN: 2442-2274 
Available online at: http://ejournal.unpas.ac.id/index.php/litigasi

Litigasi, Vol. 17(1), 2016, 3167-3220

DOI: http://dx.doi.org/10.23969/litigasi.v17i1.48

(1) ditentukan dengan undang-undang;

(2) menjaga keamanan nasional, ketertiban umum, kesehatan umum dan kesusilaan;

(3) Hak-hak dan kebebasan orang lain.

4) Pasal 21 dan Pasal 22 ayat (2) ICCPR mengatur bahwa pembatasan boleh dilakukan dengan alasan:

(1) ditentukan dengan undang-undang;

(2) diperlukan dalam suatu masyarakat demokrasi;

(3) demi kepentingan keamanan nasional, keamanan dan ketertiban umum;

(4) menjaga kesehatan dan kesusilaan umum atau menjaga hak dan kebebasan orang lain.

Berdasarkan uraian di atas, maka dapat dinyatakan bahwa hal-hal yang diatur dalam konstitusi Indonesia tersebut hakekatnya merupakan perimbangan antara hak dan kewajiban. Menurut Sefriani (Sefriani, 2012 : 3), negara menjamin berbagai hak, namun demikian negara memiliki kewenangan untuk melakukan pembatasan atau pengurangan. Adanya berbagai hak yang dijamin oleh konstitusi, bahkan ada pula hak yang dilengkapi dengan jaminan tidak dapat dikurangi dalam kondisi apapun dan oleh siapapun menjadikan adanya perbedaan status antara hak yang satu dengan hak yang lain.

Dalam konteks hak remisi bukanlah hak yang termasuk dalam Pasal 28I ayat (1) UUD 1945. Hal ini berarti hak remisi merupakan hak yang dapat dikurangi (derogable rights). Namun mengacu kepada Pasal 28 J UUD 1945, Pasal 21 dan 22 ayat (2) ICCPR, pembatasan tersebut ditentukan dengan undang-undang.

Copyright @ C 2016, LITIGASI, p-ISSN: 0853-7100; e-ISSN: 2442-2274 
Available online at: http://ejournal.unpas.ac.id/index.php/litigasi

Litigasi, Vol. 17(1), 2016, 3167-3220

DOI: http://dx.doi.org/10.23969/litigasi.v17i1.48

\section{Perlindungan Hak Narapidana}

Hak asasi manusia merupakan hak dasar manusia yang harus tetap diberikan, meskipun seseorang berada dalam keadaan sebagai narapidana. Dalam A Human Rights Approach to Prison Management terbitan International Center for Prison Studies dijelaskan bahwa "Narapidana Juga Manusia". Karena narapidana juga manusia, mereka juga memiliki hak asasi manusia, seberat apa pun kejahatan yang telah diperbuatnya. Hak asasi narapidana yang dapat dirampas hanyalah kebebasan fisik serta pembatasan hak berkumpul dengan keluarga dan hak berpartisipasi dalam pemerintahan.

Dalam rangka melindungi hak-hak asasi narapidana, termasuk tahanan, PBB pada tahun 1955 telah memformalisasi sejumlah hak dan perlakuan minimum yang harus diberikan kepada narapidana/tahanan selama berada dalam institusi penjara/penahanan, dalam bentuk Standard Minimum Rules for the Treatment of Prisoners (SMR). Ketentuan yang terdapat dalam SMR merupakan ketentuan minimal yang "secara moral" wajib ditaati dalam memperlakukan narapidana/tahanan.

Di Indonesia, jauh sebelum UU Pemasyarakatan dibuat (1995), dorongan untuk melindungi hak-hak asasi narapidana melalui pelaksanaan pemidanaan yang lebih manusiawi diawali dengan ide pemasyarakatan, yang dicetuskan oleh Sahardjo (waktu itu Menteri Kehakiman) pada waktu menerima gelar doktor honoris causa di Universitas Indonesia, tanggal 5 Juli 1963. Ide tersebut dijabarkan dalam Konferensi Direktur Penjara seluruh

Copyright $\odot$ 2016, LITIGASI, p-ISSN: 0853-7100; e-ISSN: 2442-2274 
Available online at: http://ejournal.unpas.ac.id/index.php/litigasi

Litigasi, Vol. 17(1), 2016, 3167-3220

DOI: http://dx.doi.org/10.23969/litigasi.v17i1.48

Indonesia tanggal 27 April 1964 (www.djpp.kemenkumham.go.id). Sejak tahun 1964, penjara sudah berubah menjadi "Lembaga Pemasyarakatan". Prinsip-prinsip perlakuan terhadap narapidana sudah berubah dari prinsipprinsip kepenjaraan menjadi prinsip-prinsip pemasyarakatan, yang kemudian disebut dengan Sistem Pemasyarakatan. Apabila sistem kepenjaraan masih lebih menekankan pembalasan (kepada penjahat) sebagai tujuan dari pemidanaan, maka sistem pemasyarakatan lebih menonjolkan kepada 'pemasyarakatan', ialah membina dan mengembalikan pelanggar hukum (narapidana, warga binaan) itu menjadi masyarakat yang baik kembali seperti sediakala sebelum melanggar hukum. Pemasyarakatan berarti kembali ke masyarakat menjadi warga negara yang baik dan berguna bagi masyarakat. Sistem pemasyarakatan lebih menonjolkan sisi pembinaan, bukan pembalasan, agar terpidana dapat memahami dan menyadari kesalahannya, sehingga setelah dikembalikan kepada masyarakat tidak akan mengulangi perbuatan yang melanggar hukum kembali.

Ada 10 prinsip yang dirumuskan dalam sistem pemasyarakatan melalui Konferensi Lembang, yakni (Direktorat Jenderal Pemasyarakatan Departemen Kehakiman dan HAM R.I, $2004: 82$ - 83) :

(1) Orang yang tersesat diayomi juga, dengan memberikan kepadanya bekal hidup sebagai warga yang baik dan berguna dalam masyarakat. Bekal hidup tidak hanya berupa finansial dan materi, tetapi yang lebih penting adalah mental, fisik, keahlian, keterampilan hingga orang mempunyai kemauan dan kemampuan untuk menjadi warga yang baik, tidak melanggar hukum lagi, dan berguna bagi pembangunan negara.

Copyright @ C 2016, LITIGASI, p-ISSN: 0853-7100; e-ISSN: 2442-2274 
Available online at: http://ejournal.unpas.ac.id/index.php/litigasi

Litigasi, Vol. 17(1), 2016, 3167-3220

DOI: http://dx.doi.org/10.23969/litigasi.v17i1.48

(2) Penjatuhan pidana bukan tindakan balas dendam dari negara. Terhadap narapidana tidak boleh ada penyiksaan, baik berupa tindakan, ucapan, cara perawatan maupun penempatan.

(3) Tobat tidak dapat dicapai dengan penyiksaan, melainkan dengan bimbingan. Kepada narapidana harus ditanamkan pemahaman mengenai norma-norma hidup dan kehidupan, serta diberi kesempatan untuk merenungkan perbuatannya di masa lalu. Narapidana dapat diikutsertakan dalam kegiatan-kegiatan sosial untuk menumbuhkan rasa hidup kemasyarakatan.

(4) Negara tidak berhak membuat seseorang lebih buruk atau lebih jahat daripada sebelum ia masuk lembaga. Oleh karena itu harus diadakan pemisahan antara residivis dengan yang bukan residivis, yang dijatuhi pidana berat dengan ringan, jenis tindak pidana yang dilakukan, narapidana dewasa, remaja dan anak, serta terpidana dengan tahanan.

(5) Selama kehilangan kemerdekaan bergerak, narapidana harus dikenalkan dengan dan tidak boleh diasingkan dari masyarakat. Secara bertahap, narapidana akan dibimbing di tengah-tengah masyarakat yang merupakan kebutuhan dalam proses pemasyarakatan.

(6) Pekerjaan yang diberikan kepada narapidana tidak boleh bersifat mengisi waktu, atau hanya diperuntukkan bagi kepentingan negara sewaktu-waktu saja. Pekerjaan yang diberikan harus sama dengan pekerjaan di masyarakat serta menunjang bagi usaha peningkatan produksi.

(7) Bimbingan dan didikan yang diberikan kepada narapidana harus berdasarkan Pancasila. Pendidikan dan bimbingan harus berisikan pendidikan agama, termasuk menjalankan ibadahnya, jiwa kegotongroyongan, toleransi, kekeluargaan, rasa persatuan, rasa kebangsaan Indonesia, serta jiwa bermusyawarah untuk bermufakat dalam arti yang positif. Narapidana juga harus diikutsertakan dalam kegiatan untuk kepentingan bersama dan umum.

(8) Narapidana adalah manusia dan harus diperlakukan sebagai manusia, meskipun telah tersesat. Tidak boleh selalu ditunjukkan kepada narapidana bahwa ia adalah penjahat, sehingga petugas pemasyarakatan tidak boleh bersikap maupun memakai kata-kata yang dapat menyinggung perasaannya.

(9) Narapidana hanya dijatuhi pidana kehilangan kemerdekaan. Narapidana perlu diusahakan agar memiliki mata pencaharian untuk keluarganya dengan jalan menyediakan pekerjaan dengan upah. Bagi narapidana disediakan lembaga pendidikan yang diperlukan, ataupun diberikan kesempatan untuk memperoleh pendidikan di luar lembaga.

(10) Perlu didirikan lembaga-lembaga pemasyarakatan yang baru yang sesuai dengan kebutuhan pelaksanaan program, dan memindahkan lembagalembaga yang berada di tengah kota ke tempat yang sesuai dengan kebutuhan proses pemasyarakatan.

Copyright @ 2016 , LITIGASI, p-ISSN: 0853-7100; e-ISSN: 2442-2274 
Available online at: http://ejournal.unpas.ac.id/index.php/litigasi

Litigasi, Vol. 17(1), 2016, 3167-3220

DOI: http://dx.doi.org/10.23969/litigasi.v17i1.48

Kesepuluh prinsip pemasyarakatan tersebut mengatur mengenai 'kedudukan' Pemasyarakatan sebagai perlakuan terhadap narapidana yang telah ditetapkan oleh keputusan hakim. Oleh karena itu, Pasal 1 butir 5 UU Pemasyarakatan menyebut narapidana dengan istilah warga binaan pemasyarakatan. Suatu istilah yang tidak lazim dan tidak banyak diketahui oleh masyarakat. Pemberian nama warga binaan terhadap narapidana tentu mengandung suatu makna tertentu, bahwa pelanggar hukum tidak lagi disebut sebagai penjahat, melainkan sebagai orang yang tersesat. Jadi, orang tersesat dibina di dalam lembaga pemasyarakatan supaya keluar dan bebas dari ketersesatannya (B. Simarmata, $2011: 502$ ).

Perlakuan terhadap narapidana berupa pembinaan, merupakan tugas utama dari sistem pemasyarakatan. Hal demikian dapat diketahui dari ketentuan Pasal 2 dan Pasal 3 UU Pemasyarakatan. Pasal 2 UU Pemasyarakatan menyatakan:

"Sistem pemasyarakatan diselenggarakan dalam rangka membentuk Warga Binaan Pemasyarakatan agar menjadi manusia seutuhnya, menyadari kesalahan, memperbaiki diri, dan tidak mengulangi tindak pidana sehingga dapat diterima kembali oleh lingkungan masyarakat, dapat aktif berperan dalam pembangunan, dan dapat hidup secara wajar sebagai warga yang baik dan bertanggung jawab".

Pasal 3 UU Pemasyarakatan menyatakan:

"Sistem pemasyarakatan berfungsi menyiapkan warga binaan pemasyarakatan agar dapat berintegrasi secara sehat dengan masyarakat, sehingga dapat berperan kembali sebagai anggota masyarakat yang bebas dan bertanggung jawab."

Copyright @ C 2016, LITIGASI, p-ISSN: 0853-7100; e-ISSN: 2442-2274 
Available online at: http://ejournal.unpas.ac.id/index.php/litigasi

Litigasi, Vol. 17(1), 2016, 3167-3220

DOI: http://dx.doi.org/10.23969/litigasi.v17i1.48

Dalam konteks yang lebih luas, sistem pemasyarakatan adalah sebagai bagian dari upaya perlindungan terhadap hak asasi manusia. Sebagai bagian dari Sistem Peradilan Pidana, Sistem Pemasyarakatan adalah instansi yang melakukan pemenuhan dan perlindungan hak-hak asasi tersangka, terdakwa dan terpidana. Fokus dari rumusan ini adalah bahwa Sistem Pemasyarakatan merupakan sistem perlakuan bagi tahanan dan narapidana yang dikerangkai oleh hak asasi manusia (Dindin Sudirman, 2007: 29).

Fungsi utama Sistem Pemasyarakatan dalam melindungi hak asasi manusia, ditegaskan oleh Dindin Sudirman (Dindin Sudirman, 2007) bahwa penegakan hukum oleh Pemasyarakatan merupakan upaya memanusiakan manusia. Pemasyarakatan merupakan instansi yang melakukan pemenuhan dan perlindungan hak-hak asasi tersangka (tahap pre-adjudikasi), terdakwa (tahap adjudikasi) dan terpidana (tahap post-adjudikasi). Pada tahap post-adjudikasi, unit pelaksana teknis Pemasyarakatan yang berfungsi dalam perlindungan HAM adalah Lembaga Pemasyarakatan. Fungsi lembaga pemasyarakatan, yang secara filosofis berbeda dengan penjara, merupakan upaya untuk menghindari terjadinya proses penghukuman yang tidak manusiawi. Salah satu upaya tersebut adalah mencegah terjadinya prisonisasi atau proses belajar kejahatan serta meminimalisir penderitaan dalam pemenjaraan. Menurut Didin Sudirman (Didin Sudirman, 2007), adanya hak-hak narapidana yang dilindungi oleh UU Pemasyarakatan merupakan upaya untuk memperkecil kemungkinan terjadinya prisonisasi dan stigmatisasi masyarakat.

Copyright @ C 2016, LITIGASI, p-ISSN: 0853-7100; e-ISSN: 2442-2274 
Available online at: http://ejournal.unpas.ac.id/index.php/litigasi

Litigasi, Vol. 17(1), 2016, 3167-3220

DOI: http://dx.doi.org/10.23969/litigasi.v17i1.48

Dari penjelasan di atas, dapat dinyatakan bahwa perlindungan HAM merupakan indikator utama keberhasilan tugas dan fungsi pemasyarakatan, khususnya hak-hak dari narapidana dan tahanan. Komitmen untuk mengubah kondisi narapidana tersebut, secara eksplisit ditegaskan dalam Pasal 5 UU Pemasyarakatan, bahwa sistem pembinaan pemasyarakatan dilaksanakan berdasarkan asas; pengayoman, persamaan perlakuan dan pelayanan, pendidikan, pembimbingan, penghormatan harkat dan martabat manusia, kehilangan kemerdekaan merupakan satu-satunya penderitaan, dan terjaminnya hak untuk tetap berhubungan dengan keluarga dan orang-orang tertentu. Selain itu juga dalam Pasal 14 UU Pemasyarakatan ditentukan, bahwa setiap narapidana memiliki hak sebagai berikut:

a. melakukan ibadah sesuai dengan agama atau kepercayaannya;

b. mendapat perawatan, baik perawatan rohani maupun jasmani;

c. mendapatkan pendidikan dan pengajaran;

d. mendapatkan pelayanan kesehatan dan makanan yang layak;

e. menyampaikan keluhan;

f. mendapatkan bahan bacaan dan mengikuti siaran media massa lainnya yang tidak dilarang;

g. mendapatkan upah atau premi atas pekerjaan yang dilakukan;

h. menerima kunjungan keluarga, penasihat hukum, atau orang tertentu lainnya;

i. mendapatkan pengurangan masa pidana (remisi);

j. mendapatkan kesempatan berasimilasi termasuk cuti mengunjungi keluarga;

k. mendapatkan pembebasan bersyarat;

I. mendapatkan cuti menjelang bebas; dan

m. mendapatkan hak-hak lain sesuai dengan peraturan perundangundangan yang berlaku.

Copyright @ C 2016, LITIGASI, p-ISSN: 0853-7100; e-ISSN: 2442-2274 
Available online at: http://ejournal.unpas.ac.id/index.php/litigasi

Litigasi, Vol. 17(1), 2016, 3167-3220

DOI: http://dx.doi.org/10.23969/litigasi.v17i1.48

Dari hak-hak yang telah diatur dalam Pasal 14 UU Pemasyarakatan, ada hak yang diperoleh secara otomatis, yaitu hak tersebut dalam Pasal 14 ayat (1) huruf a sampai dengan h. Namun ada hak yang baru dapat diperoleh oleh narapidana apabila telah memenuhi persyaratan tertentu. Manual Lembaga Pemasyarakatan menentukan setidaknya ada 5 (lima) hak narapidana yang diberikan apabila narapidana tersebut telah memenuhi persyaratan tertentu, yaitu: (Loebby Loqman, 2002 : 94).

1) mengadakan hubungan terbatas dengan pihak luar, maksudnya bahwa Negara tidak berhak membuat seorang narapidana menjadi lebih buruk dari sebelumnya. Selama menjalani masa hukumannya, seorang narapidana harus secara berangsur-angsur diperkenalkan dengan masyarakat dan tidak boleh diasingkan dari masyarakat, antara lain dengan cara surat menyurat dan kunjungan keluarga;

2) memperoleh remisi, yaitu memperoleh pengurangan masa pidana;

3) memperoleh asimilasi, artinya selama kehilangan kemerdekaannya, seorang narapidana harus secara berangsur-angsur diperkenalkan kepada masyarakat dan tidak boleh diasingkan dari masyarakat. Asimilasi dapat dilakukan dengan dua cara, yaitu: asimilasi ke dalam (yaitu, hadirnya masyarakat ke dalam lembaga pemasyarakatan), dan asimilasi ke luar (yaitu, hadirnya narapidana di tengah-tengah masyarakat);

4) memperoleh cuti; dan

Copyright @ C 2016, LITIGASI, p-ISSN: 0853-7100; e-ISSN: 2442-2274 
Available online at: http://ejournal.unpas.ac.id/index.php/litigasi

Litigasi, Vol. 17(1), 2016, 3167-3220

DOI: http://dx.doi.org/10.23969/litigasi.v17i1.48

5) memperoleh pembebasan bersyarat, yang merupakan hak pengintegrasian narapidana, yaitu hak narapidana untuk sepenuhnya berada di tengahtengah masyarakat, dengan syarat narapidana tersebut telah menjalani $2 / 3$ (dua per tiga) dari masa hukumannya. Narapidana yang memperoleh pembebasan bersyarat ini tetap diawasi oleh BAPAS dan Jaksa negeri setempat.

Berdasarkan penjelasan di atas, dapat diketahui bahwa hak remisi bukanlah hak yang diperoleh secara otomatis oleh narapidana, namun hak yang disertai dengan persyaratan. Hak remisi baru diterima oleh narapidana, setelah yang bersangkutan memenuhi persyaratan-persyaratan yang telah ditentukan.

3. Remisi Bagian dari Hak Narapidana

Remisi sebagai pemberian pengurangan masa hukuman bukan hal yang baru, tetapi telah lama dikenal oleh para kepala negara. Dalam sejarah perkembangannya, tradisi pemberian pengurangan masa pidana oleh kepala negara telah lama dikenal, yaitu sejak zaman pemerintahan para Kaisar Romawi dahulu kala, yang kemudian diikuti oleh para raja terutama di benua Eropa. Dahulu kala, pemberian ampunan kepada orang-orang terpidana oleh raja, dilakukan semata-mata sebagai suatu kemurahan hati sang raja berdasarkan belas kasihan. Berkaitan dengan hal tersebut, Jan Remmelink (Jan Remmelink, 2003 : 587) menyatakan bahwa pemberian ampunan adalah merupakan upaya meringankan sanksi yang dijatuhkan melalui putusan pengadilan pidana.

Copyright $\odot$ 2016, LITIGASI, p-ISSN: 0853-7100; e-ISSN: 2442-2274 
Available online at: http://ejournal.unpas.ac.id/index.php/litigasi

Litigasi, Vol. 17(1), 2016, 3167-3220

DOI: http://dx.doi.org/10.23969/litigasi.v17i1.48

Dahulu kala penguasa beranjak dari kekuasaan mutlak yang dimilikinya untuk menganugerahkan ampunan, sebagai wujud kebajikan hatinya.

Menurut pengertian dewasa ini, lembaga pemberian ampunan itu tidak lagi diberikan oleh Kepala Negara semata-mata sebagai suatu kemurahan hati dari Kepala Negara, karena dalam pemberian ampunan kepada seorang terpidana telah melibatkan pejabat-pejabat lainnya. Dalam hal ini, van Hattum (P.A.F Lamintang dan Theo Lamintang, 2010 : 269) menyatakan bahwa lembaga pemberian ampunan ini tidak boleh dipergunakan sebagai kemurahan hati dari raja, melainkan harus dipergunakan sebagai alat untuk meniadakan ketidakadilan, yaitu apabila hukum yang berlaku di dalam pemberlakuannya dapat menjurus pada suatu ketidakadilan. Kepentingan negara itu juga dapat dipakai sebagai alasan pemberian ampunan.

Dalam sejarah hukum penitensier di Indonesia, pemberian remisi bagi narapidana pertama sekali diadakan berdasarkan Gouvernement Besluit Nomor 23 tanggal 10 Agustus 1935 tentang Remissieregeling (Bijblad pada Staatsblad Nomor 13515) sebagaimana telah diubah dengan Gouvernement Besluit tanggal 9 Juli 1941 Nomor 12 (Bijblad pada Staatsblad Nomor 14583) dan tanggal 26 Januari 1942 Nomor 22 tentang Perubahan Gouvernement Besluit tanggal 10 Agustus 1935 Nomor 23 tentang Remissieregeling (Bijblad pada Staatsblad Nomor 13515). Menurut aturan ini, pemberian ampunan dilaksanakan ketika Ratu Belanda memperingati hari ulang tahunnya. Jadi, ampunan atau remisi yang diberikan oleh pemerintah

Copyright @ C 2016, LITIGASI, p-ISSN: 0853-7100; e-ISSN: 2442-2274 
Available online at: http://ejournal.unpas.ac.id/index.php/litigasi

Litigasi, Vol. 17(1), 2016, 3167-3220

DOI: http://dx.doi.org/10.23969/litigasi.v17i1.48

Belanda kepada para narapidana adalah bersifat anugerah ( $R$. Achmad S.Soemadipradja dan Romli Atmasasmita, Tanpa Tahun : 28).

Setelah Indonesia merdeka, remisi telah berubah menjadi hak narapidana (Keputusan Presiden RIS Nomor 156 Tahun 1950). Remisi tidak wajib diberikan kepada setiap narapidana. Pemberian remisi harus memenuhi syarat tertentu. Secara prinsip remisi hanya diberikan kepada narapidana yang berkelakuan baik selama menjalani pidana. Pada saat ini, masih berlaku sistem kepenjaraan.

Sistem kepenjaraan diganti dengan sistem pemasyarakatan, pada saat diselenggarakannya Konfenrensi Dinas Kepenjaraan di Lembang tahun 1964. Dengan berlakunya Sistem Pemasyarakatan, berarti terjadi pembaruan pelaksanaan pidana penjara, yang mengandung suatu kegiatan pemikiran tentang cara baru terhadap narapidana, yang didasarkan pada pendekatan pembinaan. Tujuan dari pembinaan di dalam lembaga pemasyarakatan diarahkan ke tata kehidupan yang positif bagi diri pribadi narapidana. Ketika narapidana telah dapat menunjukkan hasil perubahan perilaku menjadi baik, kepadanya diberikan beberapa hak yang bertujuan untuk mengurangi penderitaannya. Semakin cepat ditunjukkan perubahan perilaku sebagai hasil dari pembinaan itu, semakin cepat pula diakhiri atau dikurangi penderitaannya. Salah satu hak dimaksud adalah hak untuk mendapatkan pengurangan masa pidana, yakni remisi.

Copyright @ C 2016, LITIGASI, p-ISSN: 0853-7100; e-ISSN: 2442-2274 
Available online at: http://ejournal.unpas.ac.id/index.php/litigasi

Litigasi, Vol. 17(1), 2016, 3167-3220

DOI: http://dx.doi.org/10.23969/litigasi.v17i1.48

Berbeda dengan masa pemerintahan Hindia Belanda yang menganggap remisi sebagai anugerah, dalam sistem pemasyarakatan remisi telah berubah menjadi hak narapidana. Hal ini dapat dilihat dari berbagai ketentuan yang mengatur tentang remisi.

Secara yuridis formal, payung hukum berkaitan remisi telah dibuat dalam UU Pemasyarakatan; Peraturan Pemerintah (PP) Nomor 32 Tahun 1999 tentang Syarat dan Tata Cara Pelaksanaan Hak Warga Binaan Pemasyarakatan (PP Nomor 32 tahun 1999) sebagaimana telah diubah dengan PP Nomor 99 Tahun 2012; Keputusan Presiden Nomor 174 Tahun 1999 tentang Remisi (Keppres Nomor 174 Tahun 1999); Keputusan Menteri Hukum dan Perundang-undangan (sekarang Menteri Hukum dan HAM) RI Nomor. M.09.HN.02.01 Tahun 1999 tentang Pelaksanaan Keputusan Presiden Republik Indonesia Nomor 174 Tahun 1999 tentang Remisi, Peraturan Menteri Hukum dan HAM Nomor 21 Tahun 2013 tentang Syarat Dan Tata Cara Pemberian Remisi, Asimilasi, Cuti Mengunjungi Keluarga, Pembebasan Bersyarat, Cuti Menjelang Bebas, dan Cuti Bersyarat (Peraturan Menteri Hukum dan HAM Nomor 21 Tahun 2013).

Dari berbagai peraturan di atas, pengertian remisi secara tegas tercantum dalam PP Nomor 32 Tahun 1999, yaitu pengurangan masa menjalani pidana yang diberikan kepada Narapidana dan Anak Pidana yang memenuhi syarat-syarat yang ditentukan dalam peraturan perundang-undangan (Pasal 1 butir 6). Kemudian dalam Keputusan Menteri Hukum dan 
Available online at: http://ejournal.unpas.ac.id/index.php/litigasi

Litigasi, Vol. 17(1), 2016, 3167-3220

DOI: http://dx.doi.org/10.23969/litigasi.v17i1.48

Perundang-undangan RI Nomor. M.09.HN.02.01 Tahun 1999 dinyatakan bahwa remisi adalah pengurangan masa pidana yang diberikan kepada narapidana dan anak pidana yang telah berkelakuan baik selama menjalani pidana (Pasal 1 butir 1). Berdasarkan Peraturan Menteri Hukum dan HAM Nomor 21 Tahun 2013, remisi adalah pengurangan menjalani masa pidana yang diberikan kepada Narapidana dan Anak Pidana yang memenuhi syarat yang ditentukan dalam ketentuan peraturan perundang-undangan (Pasal 1 butir 1). Dalam Keppres Nomor 174 Tahun 1999 tidak ditemukan pengertian tentang remisi, hanya dinyatakan bahwa setiap narapidana dan anak pidana yang menjalani pidana sementara dan pidana kurungan dapat diberikan remisi apabila yang bersangkutan berkelakuan baik selama menjalani pidana (Pasal 1 ayat (1). Adapun dalam UU Pemasyarakatan, dikatakan bahwa narapidana berhak mendapatkan pengurangan masa pidana (remisi), tanpa mengkualifikasikan narapidana berdasarkan jenis kejahatan yang menjadikan mereka dihukum.

Berdasarkan pengertian di atas dapat dijelaskan bahwa remisi merupakan hak yang sifatnya bersyarat (conditional). Jadi, remisi bukanlah merupakan HAM par excelence, yang dapat secara serta merta diklaim oleh setiap warga binaan (Harison Citrawan, 2011 : 21). Namun untuk mendapatkan remisi, wajib dipenuhinya syarat tertentu. Secara prinsip, remisi hanya diberikan kepada narapidana yang berkelakuan baik. Hal ini dibuktikan dengan tidak sedang menjalani hukuman disiplin dalam kurun waktu 6 (enam)

Copyright @ 9 2016, LITIGASI, p-ISSN: 0853-7100; e-ISSN: 2442-2274 
Available online at: http://ejournal.unpas.ac.id/index.php/litigasi

Litigasi, Vol. 17(1), 2016, 3167-3220

DOI: http://dx.doi.org/10.23969/litigasi.v17i1.48

bulan terakhir, terhitung sebelum tanggal pemberian remisi; dan telah mengikuti program pembinaan yang diselenggarakan oleh lembaga pemasyarakatan dengan predikat baik (Pasal 34 PP Nomor 99 Tahun 2012).

Dengan demikian, dalam sistem pemasyarakatan, remisi dipakai sebagai stimulus agar setiap narapidana melakukan respon dengan berkelakuan baik selama menjalani hukumannya. Remisi sebagai hak dijadikan sarana untuk meningkatkan kualitas diri sekaligus memotivasi diri narapidana, sehingga dapat mendorong narapidana kembali memilih jalan kebenaran. Hak remisi merupakan sebuah konsekuensi atas perilaku baik, sifat kooperatif dari narapidana ketika proses pembinaan hingga bersangkutan menunjukkan penyesalan, menjadi suatu keniscayaan untuk diberikan dalam kerangka ide pemasyarakatan tersebut. Konsep ini juga telah banyak diterapkan oleh negaranegara lain di dunia, yang menjadikan remisi sebagai bagian dari pembinaan narapidana. Selain itu, hak untuk mendapatkan pengurangan masa pidana (remisi) merupakan norma universal yang dilaksanakan di beberapa negara, walaupun mengunakan sistem dan pola yang berbeda-beda (Putusan MK Nomor 022/PUU-III/2005, 19 - 22).

Pemberian remisi terhadap narapidana juga mendapat perhatian dari PBB dengan mengeluarkan aturan standar minimum berupa United Nations Standard Minimum Rules for Non-Custodial Measures, yang menegaskan perlunya alternatif tindakan setelah pemidanaan (post sentences alternatives),

Copyright @ 2016 , LITIGASI, p-ISSN: 0853-7100; e-ISSN: 2442-2274 
Available online at: http://ejournal.unpas.ac.id/index.php/litigasi

Litigasi, Vol. 17(1), 2016, 3167-3220

DOI: http://dx.doi.org/10.23969/litigasi.v17i1.48

tujuannya untuk menghindari proses institusionalisasi dan mempercepat reintegrasi sosial narapidana.

Oleh karena itu di Indonesia, dalam berbagai ketentuan mengenai remisi diatur berbagai macam remisi yang dapat diterima oleh narapidana. Pada dasarnya jenis-jenis remisi terdiri dari Remisi Umum, Remisi Khusus dan Remisi Tambahan (Pasal 2 dan Pasal 3 Keppres Nomor 174 Tahun 1999). Remisi Umum, diberikan pada hari peringatan Proklamasi Kemerdekaan Republik Indonesia tanggal 17 Agustus; dan Remisi Khusus, diberikan diberikan pada hari besar keagamaan yang dianut oleh Narapidana dan Anak Pidana yang bersangkutan, dengan ketentuan jika suatu agama mempunyai lebih dari satu hari besar. Penentuan hari besar keagamaan tersebut dicantumkan dalam Keputusan Menteri Hukum dan Perundang-undangan RI No. M.09.HN.02.01 Tahun 1999, Pasal 3 ayat (2), sebagai berikut:

Pemberian Remisi Khusus dilaksanakan pada:

(1) setiap Hari Raya Idul Fitri bagi Narapidana dan Anak Pidana yang beragama Islam;

(2) setiap Hari Natal bagi Narapidana dan Anak Pidana bagi yang beragama Kristen;

(3) setiap Hari Raya Nyepi bagi Narapidana dan Anak Pidana yang beragama Hindu;

(4) setiap Hari Raya Waisak bagi Narapidana dan Anak Pidana yang beragama Budha.

Dasar pemikiran munculnya remisi khusus ini, antara lain bahwa negara Indonesia menjamin kemerdekaan tiap penduduk untuk memeluk agamanya masing-masing termasuk bagi narapidana. Negara menganggap bahwa agama merupakan sendi utama kehidupan masyarakat, sehingga agama dapat menjadi

Copyright $\odot$ 2016, LITIGASI, p-ISSN: 0853-7100; e-ISSN: 2442-2274 
Available online at: http://ejournal.unpas.ac.id/index.php/litigasi

Litigasi, Vol. 17(1), 2016, 3167-3220

DOI: http://dx.doi.org/10.23969/litigasi.v17i1.48

alat pembinaan dalam sistem pemasyarakatan (alat modifikasi perilaku), maka hak dan kewajiban narapidana juga harus dikaitkan dengan hari raya keagamaan masing-masing. Selain itu, Indonesia sebagai bangsa yang menjunjung tinggi keberadaan agama, maka eksistensi keberadaan agama harus dirasakan sebagai hikmah bagi narapidana yang sedang mengalami penderitaan karena dibatasi kemerdekaan bergeraknya.

Pada hakekatnya, remisi diberikan kepada semua warga binaan pemasyarakatan yang berstatus narapidana dan telah memenuhi persyaratan substantif. Namun dalam pelaksanaannya ditemukan kasus-kasus narapidana dan anak pidana yang pada tanggal 17 Agustus atau pada hari besar keagamaan sesuai agama yang dianutnya telah menjalani masa penahanan paling singkat 6 (enam) bulan atau lebih dan belum menerima putusan pengadilan yang mempunyai kekuatan hukum tetap. Apabila yang bersangkutan berkelakuan baik dan lamanya masa penahanan yang dijalani tidak terputus terhitung sejak tanggal penghitungan masa penahanan memperoleh remisi sampai dengan tanggal putusan pengadilan yang mempunyai kekuatan hukum tetap, maka kepada narapidana yang bersangkutan akan diberikan Remisi Susulan (Peraturan Menteri Hukum dan Hak Asasi Manusia Republik Indonesia Nomor M.Hh-01.Pk.02.02 Tahun 2010 Tentang Remisi Susulan), yang terdiri dari Remisi Umum Susulan dan Remisi Khusus Susulan.

Copyright @ C 2016, LITIGASI, p-ISSN: 0853-7100; e-ISSN: 2442-2274 
Available online at: http://ejournal.unpas.ac.id/index.php/litigasi

Litigasi, Vol. 17(1), 2016, 3167-3220

DOI: http://dx.doi.org/10.23969/litigasi.v17i1.48

Selain Remisi Umum dan Remisi Khusus yang telah disebutkan sebelumnya, masih dapat ditambah dengan Remisi Tambahan, yang diberikan apabila narapidana atau anak pidana yang bersangkutan selama menjalani pidana: (a) berbuat jasa kepada Negara; (b) melakukan perbuatan yang bermanfaat bagi Negara atau kemanusiaan; atau (c) melakukan perbuatan yang membantu kegiatan pembinaan di Lembaga Pemasyarakatan. Penambahan jumlah remisi tersebut diharapkan dapat mendorong setiap narapidana dan anak pidana berkelakuan sedemikian rupa sehingga mereka dapat dikondisikan untuk berkelakuan baik seperti disyaratkan selama menjalankan pidananya.

Kemudian dikenal pula adanya Remisi Dasawarsa, yang diberikan pada setiap 10 tahun Hari Ulang Tahun Kemerdekaan Republik Indonesia. Remisi dasawarsa pertama kali diatur dalam Keputusan Presiden Republik Indonesia No. 120 Tahun 1955 tentang Pengurangan Hukuman Istimewa pada hari Dwi Dasawarsa Proklamasi Kemerdekaan RI. Kemudian pada tahun 2005, Menkum HAM menerbitkan Keputusan No. M.01-HN.02.01 Tahun 2005 tentang Penetapan Pengurangan Masa Hukuman Secara Khusus Pada Peringatan 60 Tahun Kemerdekaan Republik Indonesia. Pemberian remisi dasawarsa selanjutnya akan diberikan pada tahun 2015.

Dari berbagai jenis remisi (mulai dari remisi umum, remisi khusus, remisi tambahan, dan remisi dasawarsa), besaran remisi yang diterima oleh para narapidana tersebut berbeda-beda. Pada tahun pertama (Pasal 4 Keppres Nomor 174 Tahun 1999), besarnya remisi umum adalah 1 (satu) bulan bagi

Copyright $\odot$ 2016, LITIGASI, p-ISSN: 0853-7100; e-ISSN: 2442-2274 
Available online at: http://ejournal.unpas.ac.id/index.php/litigasi

Litigasi, Vol. 17(1), 2016, 3167-3220

DOI: http://dx.doi.org/10.23969/litigasi.v17i1.48

narapidana dan anak pidana yang telah menjalani pidana selama 6 (enam) sampai 12 (dua belas) bulan, dan 2 (dua) bulan bagi narapidana dan anak pidana yang telah menjalani pidana selama 12 (dua belas) bulan atau lebih. Pada tahun kedua diberikan remisi 3 (tiga) bulan, tahun ketiga diberikan remisi 4 (empat) bulan, tahun keempat dan kelima masing-masing diberikan remisi 5 (lima) bulan, dan tahun keenam dan seterusnya diberikan remisi 6 (enam) bulan setiap tahun.

Besarnya remisi khusus adalah 15 (lima belas) hari bagi narapidana dan anak pidana yang telah menjalani pidana selama 6 (enam) sampai 12 (dua belas) bulan; dan 1 (satu) bulan bagi narapidana dan anak pidana yang telah menjalani pidana selama 12 (dua belas) bulan atau lebih. Pada tahun kedua dan ketiga masing-masing diberikan remisi 1 (satu) bulan, tahun keempat dan kelima masing-masing diberikan remisi 1 (satu) bulan 15 (lima belas) hari, dan tahun keenam dan seterusnya diberikan remisi 2 (dua) bulan setiap tahun.

Remisi Tambahan, besarnya adalah setengah dari remisi umum yang diperoleh pada tahun yang bersangkutan bagi narapidana dan anak pidana yang berbuat jasa kepada negara atau melakukan perbuatan yang bermanfaat bagi negara atau kemanusiaan, dan sepertiga dari remisi umum yang diperoleh pada tahun yang bersangkutan bagi narapidana dan anak pidana yang telah melakukan perbuatan yang membantu kegiatan pembinaan di lembaga pemasyarakatan sebagai pemuka.

Copyright @ C 2016, LITIGASI, p-ISSN: 0853-7100; e-ISSN: 2442-2274 
Available online at: http://ejournal.unpas.ac.id/index.php/litigasi

Litigasi, Vol. 17(1), 2016, 3167-3220

DOI: http://dx.doi.org/10.23969/litigasi.v17i1.48

Adapun besaran remisi dasawarsa adalah satu per dua belas dari masa pidana, dengan maksimum pengurangan tiga bulan. Misalnya, untuk masa pidana dua tahun (24 bulan), remisi dasawarsa yang akan diberikan adalah dua bulan. Untuk hukuman dengan masa pidana lebih dari tiga tahun, remisi dasawarsa yang dapat diberikan adalah maksimum 3 bulan.

Dengan demikian, berarti ada beberapa jenis remisi yang dapat diterima oleh narapidana dan anak pidana, yakni remisi umum, remisi khusus, remisi tambahan dan remisi dasawarsa. Keberadaan masing-masing remisi tersebut adalah diperuntukan untuk mendukung proses reintegrasi sosial narapidana sesuai dengan filosofi sistem pemasyarakatan.

Banyaknya jenis remisi tersebut, apabila ditinjau dari aspek sistem pemasyarakatan, maka remisi bukan dimaksudkan untuk kemudahan dalam kebijakan menjalani pidana, sehingga mengurangi arti pemidanaan, melainkan mempunyai tujuan untuk (Menteri Hukum dan HAM, 17 Agustus 2008):

(1) Lebih memotivasi serta dijadikan alat mengingatkan narapidana dan anak pidana untuk berkelakuan baik secara terus menerus dalam rangka mempercepat proses reintegrasi sosial yang bersangkutan.

(2) Sejalan dengan fungsi pemasyarakatan sebagai bagian integral dari sistem pemidanaan dalam tata peradilan pidana, sehingga pemberian remisi tersebut adalah dalam upaya untuk mengurangi dampak negatif dan sub kultur tempat pelaksanaan pidana, disparitas pidana dan akibat perampasan kemerdekaan.

Copyright @ 2016 , LITIGASI, p-ISSN: 0853-7100; e-ISSN: 2442-2274 
Available online at: http://ejournal.unpas.ac.id/index.php/litigasi

Litigasi, Vol. 17(1), 2016, 3167-3220

DOI: http://dx.doi.org/10.23969/litigasi.v17i1.48

(3) Secara psikologis pemberian remisi memberikan pengaruh untuk menekan tingkat frustasi (terutama bagi narapidana residivis), sehingga dapat mereduksi atau meminimalisasi gangguan keamanan dan ketertiban di dalam lembaga pemasyarakatan.

(4) Perubahan pidana penjara seumur hidup menjadi pidana sementara diberikan dalam rangka pelaksanaan hak-hak narapidana dengan memberikan kesempatan kepada narapidana yang dijatuhi pidana seumur hidup memperbaiki diri dan mempunyai harapan untuk kembali ke tengahtengah masyarakat melalui proses pemasyarakatan sebagaimana narapidana lainnya.

Sementara itu, konsekuensi yuridis dari pemberian remisi kepada narapidana sesuai Keppres R.I. Nomor 174 Tahun 1999, bahwa pemberian remisi mengakibatkan berkurangnya masa pidana yang masih harus dijalani oleh narapidana dan pengurangan masa pidana tersebut dapat menyebabkan pembebasan seketika oleh yang bersangkutan. Pembebasan diberikan kepada narapidana atau anak pidana, yang setelah dikurangi remisi umum maupun remisi tambahan, masa pidana yang harus dijalani ternyata mengakibatkan masa pidananya habis, tepat pada saat pemberian remisi yaitu pada tanggal 17 Agustus pada tahun yang bersangkutan.

Konsekuensi yuridis lainnya, bahwa masa pembebasan bersyarat menjadi lebih singkat. Pembebasan bersyarat diberikan kepada narapidana maupun anak pidana yang telah menjalani masa pidana selama $2 / 3$ (dua per tiga), sekurang-

Copyright @ 9 2016, LITIGASI, p-ISSN: 0853-7100; e-ISSN: 2442-2274 
Available online at: http://ejournal.unpas.ac.id/index.php/litigasi

Litigasi, Vol. 17(1), 2016, 3167-3220

DOI: http://dx.doi.org/10.23969/litigasi.v17i1.48

kurangnya telah menjalani pidananya selama 9 (sembilan) bulan. Dengan pemberian remisi berarti akan mengurangi masa pidana narapidana atau anak pidana yang bersangkutan. Keadaan ini akan mengakibatkan masa pembebasan bersyarat menjadi lebih singkat. Akibat hukum lainnya adalah remisi yang di dalamnya mengatur pula ketentuan mengenai komutasi atau perubahan pidana penjara seumur hidup menjadi pidana penjara sementara waktu 15 tahun, dengan syarat antara lain yang bersangkutan telah menjalani pidana paling sedikit 5 (lima) tahun berturut-turut dan berkelakuan baik (Pasal 9 Keppres R.I Nomor 174 Tahun 1999).

Berdasarkan uraian di atas dapat dijelaskan bahwa hukum positif yang mengatur tentang pemberian remisi kepada narapidana telah mencerminkan diakui dan diterapkannya konsep pemasyarakatan dalam kerangka pemidanaan dan pembinaan narapidana. Remisi yang ada tidak serta merta diberikan kepada narapidana, namun ada tahapan dan proses serta syarat dari setiap jenis remisi yang harus dipenuhi oleh narapidana untuk mendapatkannya. Keadaan demikian menunjukkan bahwa keberadaan remisi itu adalah sebagai bentuk apresiasi atau reward atas perbuatan atau perilaku positif dari narapidana. Dengan demikian, remisi hadir sebagai bentuk rangsangan (stimulus) agar narapidana senantiasa terus berusaha untuk berkelakuan baik, dalam arti ada pertobatan yang tentunya adalah juga dalam rangka mengembalikannya kepada kehidupan di tengah masyarakat (reintegrasi sosial).

Copyright $\odot$ 2016, LITIGASI, p-ISSN: 0853-7100; e-ISSN: 2442-2274 
Available online at: http://ejournal.unpas.ac.id/index.php/litigasi

Litigasi, Vol. 17(1), 2016, 3167-3220

DOI: http://dx.doi.org/10.23969/litigasi.v17i1.48

Pemberian remisi yang tidak dilakukan dengan serta merta kepada narapidana, dimaksudkan juga agar dapat dilakukan evaluasi terhadap perbuatan narapidana yang bersangkutan. Tentu tidaklah tepat, remisi tetap diberikan kepada narapidana yang perbuatannya dalam kurun waktu tertentu dinilai buruk. Tujuan dilakukannya evaluasi agar filosofi pemberian remisi kepada narapidana tidak bergeser menjadi sekedar ketentuan prosedural hukum positif semata, yang tentunya dengan tidak mengurangi makna dari hak narapidana tersebut.

4. Kebijakan Remisi bagi Narapidana Kasus Korupsi

Remisi merupakan hak bagi setiap narapidana, apapun pelanggaran dan kejahatan yang telah dilakukannya, karena hal tersebut merupakan satu kesatuan yang tak bisa terpisahkan dari sistem peradilan pidana. Kebijakan menghilangkan remisi justru akan merusak tatanan sistem peradilan pidana. Karena tujuan dari pemidanaan di Indonesia adalah memasyarakatkan kembali para pelaku kejahatan, sehingga dapat bersosialisasi lagi dengan baik. Negara Indonesia yang menganut sistem pemidanaan yang bersifat restorative justice memiliki dampak bahwa Indonesia tidak ingin membalas, namun dengan sistem tersebut berupaya untuk memulihkan kembali keadaan pelaku. Hal tersebut didasarkan pada pandangan bahwa seseorang yang melakukan tindak pidana memiliki kelainan sifat sehingga pemberian sanksi pidana bermaksud untuk memulihkan kembali keadaan si pelaku. Dengan demikian dapatlah diketahui bahwasanya remisi yang merupakan bagian dalam sistem peradilan pidana

Copyright $\odot$ 2016, LITIGASI, p-ISSN: 0853-7100; e-ISSN: 2442-2274 
Available online at: http://ejournal.unpas.ac.id/index.php/litigasi

Litigasi, Vol. 17(1), 2016, 3167-3220

DOI: http://dx.doi.org/10.23969/litigasi.v17i1.48

Indonesia harus tetap lah ada, ini dikarenakan bahwasanya Indonesia tidak menganut pola pemidanaan dengan pembalasan namun lebih kepada sistem restorative justice yaitu pemulihan kembali keadaan pelaku tindak pidana.

Remisi merupakan hak narapidana (Pasal 14 ayat (1) huruf i UU Pemasyarakatan). Setiap narapidana berhak untuk mendapatkan pengurangan hukuman (remisi) apabila telah memenuhi syarat yang ada yang diatur dalam Pasal 34 ayat (2) PP Nomor 99 Tahun 2012, yakni berkelakuan baik dan telah menjalani masa pidana lebih dari 6 (enam). Khusus untuk narapidana kasus korupsi juga harus memenuhi Pasal 34A ayat (1) huruf a dan $b$ Peraturan Pemerintah Nomor 99 Tahun 2012, yang menentukan:

(a) bersedia bekerjasama dengan penegak hukum untuk membantu membongkar perkara tindak pidana yang dilakukannya;

(b) telah membayar lunas denda dan uang pengganti sesuai dengan putusan pengadilan untuk Narapidana yang dipidana karena melakukan tindak pidana korupsi.

Sepintas PP Nomor 99 Tahun 2012 tampak berpihak pada kepentingan negara dan kepentingan perlindungan masyarakat luas. Akan tetapi, bila dicermati lebih mendalam, terdapat pemberian hak remisi bagi narapidana pelaku tindak pidana korupsi yang berbeda dengan pelaku tindak pidana umum lainnya. Pada prinsipnya, baik narapidana kasus korupsi, maupun narapidana pelaku tindak pidana lainnya tetap mendapatkan hak yang sama untuk mendapatkan remisi, dan hak tersebut telah dilindungi oleh $\mathrm{UU}$ Pemasyarakatan. Dengan adanya Peraturan Pemerintah tersebut, saat ini tidak semua narapidana kasus korupsi dengan mudah akan mendapatkan remisi

Copyright $\odot$ 2016, LITIGASI, p-ISSN: 0853-7100; e-ISSN: 2442-2274 
Available online at: http://ejournal.unpas.ac.id/index.php/litigasi

Litigasi, Vol. 17(1), 2016, 3167-3220

DOI: http://dx.doi.org/10.23969/litigasi.v17i1.48

sebagaimana halnya narapidana pelaku tindak pidana umum lainnya, karena selain berkelakuan baik dan telah menjalani masa pidana selama 6 bulan, masih terdapat aturan syarat yang lebih khusus yang harus dipenuhi sebagaimana diatur dalam Pasal 34A ayat (1) huruf a dan b PP Nomor 99 Tahun 2012, yaitu mengenai kesediaannya bekerjasama dengan penegak hukum untuk membantu membongkar perkara tindak pidana yang dilakukannya (justice collaborator). Kesediaan untuk bekerjasama tersebut harus dinyatakan secara tertulis dan ditetapkan oleh instansi penegak hukum. Syarat berikutnya untuk dapat diberikan remisi adalah yang bersangkutan telah membayar lunas denda dan uang pengganti sesuai dengan putusan pengadilan. Selanjutnya, remisi untuk narapidana tersebut diberikan oleh Menteri Hukum dan HAM, setelah mendapatkan pertimbangan tertulis lebih dahulu dari pimpinan lembaga terkait.

Kebijakan pemberian remisi bagi narapidana pelaku tindak pidana korupsi, meskipun telah diatur dalam PP Nomor 99 Tahun 2012 sebagai menindaklanjuti ketentuan Pasal 14 ayat (2) UU Pemasyarakatan, namun penolakan terhadap kebijakan pemerintah yang memperketat pemberian remisi bagi narapidana kasus korupsi tetap terjadi. Hal ini disebabkan dalam hal pemberian remisi kepada narapidana khususnya pelaku tindak pidana korupsi, terdapat dua dimensi hak, yakni hak narapidana pelaku tindak pidana korupsi dan hak rakyat yang menanggung dampak dari tindak pidana korupsi.

Copyright @ 2016 , LITIGASI, p-ISSN: 0853-7100; e-ISSN: 2442-2274 
Available online at: http://ejournal.unpas.ac.id/index.php/litigasi

Litigasi, Vol. 17(1), 2016, 3167-3220

DOI: http://dx.doi.org/10.23969/litigasi.v17i1.48

Apabila kepada narapidana pelaku tindak pidana korupsi tidak diberikan atau dibatasi hak remisinya dinyatakan melanggar hak asasi manusia dan sistem pemasyarakatan itu sendiri atau dengan kata lain kebijakan pembatasan tersebut seolah mengembalikan lagi sistem pemidanaan di Indonesia ke dalam sistem kepenjaraan. Remisi adalah instrumen dari pemasyarakatan yang bertujuan untuk memotivasi narapidana untuk senantiasa berbuat baik, sehingga dengan kebijakan untuk tidak memberikan remisi kepada narapidana kasus korupsi adalah bertentangan dengan filosofi pemidanaan yang preventif, rehabilitatif dan reintegrasi sosial yang keseluruhannya tercakup dalam sistem pemasyarakatan. Remisi adalah hak narapidana yang diberikan dalam rangka pembinaan. Kebijakan mencabut hak memperoleh remisi sama saja dengan mengulang kembali proses pemidanaan kepada narapidana tersebut, karena proses pemidanaan telah selesai dengan dijatuhkannya putusan hakim yang berkekuatan hukum tetap. Selanjutnya, proses pembinaan narapidana tersebut dan hak memperoleh remisi adalah bagian dari proses pembinaan dalam sistem pemasyarakatan.

Sebaliknya jika kepada narapidana pelaku tindak pidana korupsi tetap diberikan remisi dengan kenyataan yang telah diuraikan sebelumnya, maka dianggap melanggar hak asasi rakyat. Hal ini dikarenakan kejahatan korupsi tidak berakibat langsung pada satu atau dua orang saja, tetapi dampak yang ditimbulkannya sangat luas dan berakibat buruk pada banyak aspek kehidupan masyarakat, utamanya dalam kehidupan berbangsa dan bernegara.

Copyright @ C 2016, LITIGASI, p-ISSN: 0853-7100; e-ISSN: 2442-2274 
Available online at: http://ejournal.unpas.ac.id/index.php/litigasi

Litigasi, Vol. 17(1), 2016, 3167-3220

DOI: http://dx.doi.org/10.23969/litigasi.v17i1.48

Oleh sebab itu, agar penegakan hukum berkaitan pemberian remisi dapat efektif diterapkan bagi narapidana pelaku tindak pidana korupsi, maka aspek keadilan, kepastian hukum, kemanfaatan harus diperhatikan dan dalam penerapannya perlu dilakukan secara konsekuen serta konsisten.

\section{Aspek Keadilan}

Keadilan memang merupakan konsepsi yang abstrak. Namun demikian di dalam konsep keadilan terkandung makna perlindungan hak, persamaan derajat dan kedudukan di hadapan hukum, serta asas proporsionalitas antara kepentingan individu dan kepentingan sosial (Moh. Mahfud MD, 2009 : 3). Apabila berbicara mengenai aspek keadilan dalam hal pemberian remisi bagi narapidana pelaku tindak pidana korupsi, maka terlebih dahulu harus didikotomikan antara keadilan rakyat di satu sisi dan keadilan koruptor di sisi lain.

Rakyat memiliki hak untuk sejahtera, hak untuk bersekolah di sekolah/perguruan tinggi yang baik, hak untuk mendapatkan pekerjaan yang layak dan bermartabat sesuai kemampuannya dan seterusnya. Pemerintah wajib melakukan upaya untuk pemenuhan hak-hak tersebut melalui pembangunan yang terencana dan berkeadilan. Tetapi hak-hak tersebut sulit didapatkan oleh sebagian besar rakyat karena anggaran untuk itu banyak diselewengkan untuk kepentingan pribadi oknum penyelenggara negara. Dari hasil penelitian yang dilakukan oleh Pusat Penelitian dan Pelatihan Ekonomika dan Bisnis Universitas Gajah Mada (P2EB UGM) tahun 2011 -

Copyright @ 2016 , LITIGASI, p-ISSN: 0853-7100; e-ISSN: 2442-2274 
Available online at: http://ejournal.unpas.ac.id/index.php/litigasi

Litigasi, Vol. 17(1), 2016, 3167-3220

DOI: http://dx.doi.org/10.23969/litigasi.v17i1.48

2012 bahwa kerugian negara akibat perbuatan korupsi adalah Rp. 168,19 Trilyun, sedangkan jumlah hukuman finansial yang dikembalikan hanya $R p$. 15,09 Trilyun, berarti total kerugian negara adalah Rp.153,1 Trilyun. Jumlah tersebut apabila digunakan untuk kepentingan rakyat, setara dengan biaya kuliah untuk 2,5 juta mahasiswa S1 - S3, Bantuan Langsung Tunai (BLT) Rp.100.000 untuk 127 juta warga dan untuk pembangungan 102.000 puskesmas (Mata Najwa, 26 November 2014). Namun, itu semua tidak diperoleh karena rakyat pembayar pajak ikut menanggung akibat dari perbuatan para koruptor, bahkan dapat dikatakan bahwa rakyat juga ikut mensubsidi para koruptor yang berada di dalam lembaga pemasyarakatan. Angka tersebut sekedar untuk memberi ilustrasi akan betapa besar kerugian rakyat akibat korupsi.

Di sisi lain, ancaman pidana yang diterima oleh para koruptor juga sangat rendah, menurut penelitian ICW dalam skala 1 - 20 tahun, maka rata-rata vonis koruptor hanya 3,6 bulan saja (http://nasional.kompas.com). Dengan jenis remisi yang bermacammacam, maka tidak sampai setengah dari masa hukuman yang dijatuhkan, yang bersangkutan sudah dapat memperoleh pembebasan bersyarat. Paling tidak, kasus Artalita Suryani, Urip Tri Gunawan dan Anggodo Widjojo dapat mewakili bentangan fakta tersebut.

Untuk mencegah pemberian remisi yang berlebihan, maka perlu ditata kembali sistem pemberian remisi. Resmi cukup diberikan setahun

Copyright @ 2016 , LITIGASI, p-ISSN: 0853-7100; e-ISSN: 2442-2274 
Available online at: http://ejournal.unpas.ac.id/index.php/litigasi

Litigasi, Vol. 17(1), 2016, 3167-3220

DOI: http://dx.doi.org/10.23969/litigasi.v17i1.48

sekali saja, misalnya pada peringatan hari Kemerdekaan 17 Agustus, mengingat pada awalnya remisi diberikan karena adanya hubungan negara dengan rakyat. Kemudian, remisi yang merupakan hak bagi setiap narapidana juga telah diatur dalam undang-undang, sehingga jangan sampai terjadi perbuatan tidak adil bagi pelaku tindak pidana korupsi, karena tidak diberikan hak remisinya. Oleh karena itu perlu ditinjau ulang regulasi tentang sistem pemberian remisi tersebut. Hal tersebut juga berguna untuk memastikan remisi diberikan pada orang yang tepat.

2. Aspek Kepastian Hukum

Kepastian hukum sebagai salah satu tujuan hukum dapat dikatakan sebagai bagian dari upaya mewujudkan keadilan. Bentuk nyata dari kepastian hukum adalah pelaksanaan atau penegakan hukum terhadap suatu tindakan tanpa memandang siapa yang melakukan. Dengan adanya kepastian hukum setiap orang dapat memperkirakan apa yang akan dialami jika melakukan tindakan hukum tertentu. Kepastian diperlukan untuk mewujudkan prinsip persamaan dihadapan hukum tanpa diskriminasi (Moh. Mahfud MD, 2009 : 3).

Secara individual narapidana kasus korupsi juga manusia yang memiliki hak yang diberikan oleh berbagai instrumen hukum nasional maupun internasional, sebagai berikut:

Copyright @ C 2016, LITIGASI, p-ISSN: 0853-7100; e-ISSN: 2442-2274 
Available online at: http://ejournal.unpas.ac.id/index.php/litigasi

Litigasi, Vol. 17(1), 2016, 3167-3220

DOI: http://dx.doi.org/10.23969/litigasi.v17i1.48

1) Pasal 28 D ayat (1) UUD 1945 yang menyatakan "Setiap orang berhak atas pengakuan, jaminan, perlindungan, dan kepastian hukum yang adil serta perlakuan yang sama dihadapan hukum".

2) Pasal 28 I ayat (2) yang menyatakan "Setiap orang berhak bebas atas perlakuan yang bersifat diskriminatif atas dasar apapun dan berhak mendapatkan perlindungan terhadap perlakuan yang bersifat diskriminatif tersebut".

3) Pasal 3 ayat (2) Undang-Undang Nomor 39 Tahun 1999 tentang Hak Asasi Manusia (UU HAM) yang menyatakan: 'Setiap orang berhak atas pengakuan, jaminan, perlindungan, dan perlakuan hukum yang adil serta mendapat kepastian hukum dan perlakuan yang sama didepan hukum".

4) Pasal 4 UU HAM menentukan: "Hak untuk hidup, hak untuk tidak disiksa, hak kebebasan pribadi, pikiran dan hati nurani, hak beragama, hak untuk tidak diperbudak, hak untuk diakui sebagai pribadi dan persamaan di hadapan hukum dan hak untuk tidak dituntut atas dasar hukum yang berlaku surut adalah hak asasi manusia yang tidak dapat dikurangi dalam keadaan apapun dan oleh siapapun".

5) Pasal 17 UU HAM: "Setiap orang tanpa diskriminasi, berhak untuk memperoleh keadilan dengan mengajukan permohonan, pengaduan dan gugatan, baik dalam perkara pidana, perdata maupun administrasi serta diadili melalui proses peradilan yang bebas dan tidak memihak sesuai dengan hukum acara yang menjamin pemeriksaan yang objektif oleh

Copyright @ C 2016, LITIGASI, p-ISSN: 0853-7100; e-ISSN: 2442-2274 
Available online at: http://ejournal.unpas.ac.id/index.php/litigasi

Litigasi, Vol. 17(1), 2016, 3167-3220

DOI: http://dx.doi.org/10.23969/litigasi.v17i1.48

hakim yang jujur dan adil untuk memperoleh putusan yang adil dan benar".

6) Pasal 14 ayat (1) huruf i UU Pemasyarakatan, menyatakan bahwa narapidana berhak mendapat pengurangan masa pidana (remisi).

7) ICPPR yang telah diratifikasi dengan UU Nomor 12 Tahun 2005, dalam Pasal 10 ICCPR menyatakan dalam ayat (1): All persons deprived of their liberty shall be treated with humanity and with respect for the inherent dignity of the human person (Setiap orang yang dirampas kebebasannya wajib diperlakukan secara manusiawi dan dengan menghormati martabat yang melekat pada diri manusia) dan selanjutnya dalam ayat (4) dinyatakan bahwa The Penitentiary system shall comprise treatment of prisoners the essential aim of which shall be their reformation and social rehabilitation (Sistem pemasyarakatan harus memiliki tujuan utama memperbaiki dan melakukan rehabilitasi dalam memperlakukan narapidana). Hal ini berarti ICCPR mengakui tegas dan jelas bahwa orang hukuman masih memiliki kehormatan (dignity) sebagai manusia dan sistem pemasyarakatan harus memperlakukan narapidana dengan tujuan utama untuk memperbaiki dan melakukan rehabilitasi sosial.

8) UNCAC, Konvensi PBB Anti Korupsi 2003 dalam Pasal 30 ayat (10) menegaskan bahwa setiap negara peratifikasi wajib (mandatory obligation) melaksanakan reintegrasi narapidana korupsi ke dalam 
Available online at: http://ejournal.unpas.ac.id/index.php/litigasi

Litigasi, Vol. 17(1), 2016, 3167-3220

DOI: http://dx.doi.org/10.23969/litigasi.v17i1.48

masyarakat. Konvensi PBB Anti Korupsi 2003 sama sekali tidak memberikan mandat kepada negara peratifikasi untuk menunda atau meniadakan pemberian remisi atau bebas bersyarat kepada narapidana kasus korupsi.

Dengan melihat kepada ketentuan di atas yang memberikan jaminan perlindungan terhadap narapidana, maka sebenarnya tidak terdapat celah yang memperbolehkan adanya pembedaan perlakuan terhadap narapidana pelaku tindak pidana korupsi dengan narapidana pelaku tindak pidana umum lainnya termasuk dalam pemberian hak. Apalagi dalam UU Pemasyarakatan, khususnya Pasal 5 huruf $b$ telah diatur bahwa pembinaan narapidana dilaksanakan dengan asas persamaan perlakuan dan pelayanan; dan dalam Pasal 14 ayat (1) UU Pemasyarakatan juga dicantumkan bahwa setiap narapidana berhak mendapatkan pengurangan masa pidana (remisi), tanpa dibedakan berdasarkan jenis tindak pidananya.

Namun, jika melihat kepada sifat hak asasi manusia yang melekat secara kodrati pada manusia (inherent dignity of men), bahwa ada hak yang dikatakan tidak dapat dihapus atau dicabut (inalienable rights) dan karena itu pula tidak boleh dilanggar (inviolable). Sifat hak asasi manusia inilah yang membedakannya dengan hak-hak yang diberikan oleh hukum (legal rights). Pembedaan ini adalah penting, karena hak yang diberikan oleh hukum dapat diberikan pembatasan, sedangkan terhadap hak asasi manusia tidak dapat diberikan pembatasan (Mardjono Reksodiputro, 2007 : 161).

Copyright @ 2016 , LITIGASI, p-ISSN: 0853-7100; e-ISSN: 2442-2274 
Available online at: http://ejournal.unpas.ac.id/index.php/litigasi

Litigasi, Vol. 17(1), 2016, 3167-3220

DOI: http://dx.doi.org/10.23969/litigasi.v17i1.48

Hak-hak yang tidak dapat dibatasi adalah hak-hak yang bersifat absolut (non derogable rights) sebagaimana dinyatakan dalam Pasal 28 I ayat (1) UUD 1945, sedangkan hak-hak yang dapat dibatasi hanyalah hak-hak relatif (derogable rights). Pembatasan tersebut sesuai Pasal 28 Jayat (2) UUD 1945 harus melalui penetapan undang-undang.

Berkaitan dengan hak remisi narapidana, dari perspektif hak asasi manusia, remisi bukan termasuk non derogable rights, berarti dapat dilakukan pembatasan, hanya saja pembatasan tersebut dilakukan melalui penetapan undang-undang (Pasal 28 J ayat (2) UUD 1945). Kemudian, dari perspektif hukum pemasyarakatan, pemberian remisi bagi narapidana secara hukum memang dibenarkan. Remisi merupakan hak narapidana (Pasal 14 ayat (1) UU Pemasyarakatan. Namun hak tersebut tidak sertamerta dapat diberikan kepada narapidana. Ada syarat-syarat dan tata cara yang wajib dipenuhi. Karena itu, dapat dikatakan bahwa dari hukum pemasyarakatan, hak memperoleh remisi adalah hak yang terbatas, yakni dibatasi oleh syarat dan tata cara tertentu. Hak remisi dapat diperoleh jika syarat dan tata cara dipenuhi oleh narapidana.

Pasal 14 ayat (2) UU Pemasyarakatan memberi kewenangan kepada pemerintah untuk mengatur mengenai syarat dan tata cara pelaksanaannya. Dari sinilah pemerintah memperoleh kewenangan atribusi untuk mengatur perihal tersebut. Sehingga pemerintah mengeluarkan peraturan pemerintah yang secara teknis memberikan panduan berkaitan dengan syarat dan tata

Copyright @ 2016 , LITIGASI, p-ISSN: 0853-7100; e-ISSN: 2442-2274 
Available online at: http://ejournal.unpas.ac.id/index.php/litigasi

Litigasi, Vol. 17(1), 2016, 3167-3220

DOI: http://dx.doi.org/10.23969/litigasi.v17i1.48

cara pemberian remisi. Di sinilah pemerintah membuat kebijakan hukum. Pilihan kebijakan pemerintah boleh jadi mempermudah atau mempersulit pelaksanaan remisi. Namun peraturan pemerintah yang diterbitkan tidaklah boleh bertentangan dengan undang-undang karena dalam UU Pemasyarakatan tidak memberi kualifikasi tindak pidana yang telah dilakukan. Oleh karena itu, apabila akan dilakukan pengecualian, maka perlu dilakukan revisi terhadap UU Pemasyarakatan yang ada sekarang ini.

\section{Asas Kemanfaatan}

Kebijakan hukum pidana yang diterapkan dalam penegakan hukum terhadap pemberian remisi bagi pelaku tindak pidana korupsi harus dapat mewujudkan tujuan hukum terutama kemanfaatannya bagi negara maupun masyarakat, karena tujuan akhir dari kebijakan hukum pidana adalah kesejahteraan masyarakat. Mengingat bahwa tindak pidana korupsi merupakan tindak pidana yang melanggar hak sosial dan hak ekonomi rakyat, maka dalam penegakan hukum pemberantasan tindak pidana korupsi lebih menekankan ke arah pemberantasan aset pelaku tindak pidana korupsi. Dengan demikian, diharapkan dapat tercapai kesejahteraan masyarakat. sesuai dengan Alinea IV Pembukaan UUD 1945 dan juga menjadi landasan dari politik hukum pidana di Indonesia.

Copyright @ 2016 , LITIGASI, p-ISSN: 0853-7100; e-ISSN: 2442-2274 
Available online at: http://ejournal.unpas.ac.id/index.php/litigasi

Litigasi, Vol. 17(1), 2016, 3167-3220

DOI: http://dx.doi.org/10.23969/litigasi.v17i1.48

5. Kebijakan Remisi bagi Narapidana Kasus Korupsi untuk Masa yang akan Datang

Haruslah diakui bahwa secara umum persoalan korupsi, tidak hanya mengakibatkan kerugian keuangan negara, tetapi dapat mengakibatkan dampak yang sangat luas, baik di bidang sosial, ekonomi, keamanan, politik, dan budaya. Menurut Romli Atmasasmita, korupsi selain menyengsarakan rakyat, juga melanggar hak-hak ekonomi dan sosial rakyat. sebagai kejahatan yang serius dan menjadi beban berat bagi setiap negara (Romli Atmasasmita, 2004 : 48). Namun, kebijakan yang membedakan remisi narapidana pelaku tindak pidana korupsi dengan narapidana lainnya dapat menjadi masalah diskriminasi, karena dari sistem pemidanaan perlu dipahami bahwa korupsi memang sebagai kejahatan yang harus ditangani secara luar biasa, baik dalam tingkat penyidikan maupun pada tingkat pemeriksaan di depan pengadilan. Akan tetapi, bagi seseorang yang telah diputuskan bersalah melakukan tindak pidana (apapun jenis tindak pidananya) oleh pengadilan yang berkekuatan hukum tetap, seketika itu mengubah status terdakwa menjadi terpidana. Pada saat terpidana ditempatkan dalam lembaga pemasyarakatan dan menyandang status narapidana, maka tidak ada lagi perlakuan-perlakuan yang luar biasa terhadap mereka, semuanya memiliki hak mendasar sebagai hak asasi yang sama, tanpa adanya diskriminasi pemidanaan, suatu equal rights without punishment discrimination, untuk mendapatkan remisi sebagai hak. Keberadaan mereka di dalam lembaga pemasyarakatan bukan termasuk ranah penegakan hukum (law enforcement) lagi, melainkan ranah pembinaan narapidana (treatment). Atas dasar pembedaan tersebut maka sejak lama telah diakui perbedaan yang

Copyright @ C 2016, LITIGASI, p-ISSN: 0853-7100; e-ISSN: 2442-2274 
Available online at: http://ejournal.unpas.ac.id/index.php/litigasi

Litigasi, Vol. 17(1), 2016, 3167-3220

DOI: http://dx.doi.org/10.23969/litigasi.v17i1.48

signifikan antara penghukuman (punishment) di satu sisi dan pembinaan narapidana (treatment of prisoners) di sisi lain.

Oleh karena itu, kebijakan untuk tidak memberikan atau membedakan syarat remisi bagi narapidana pelaku tindak pidana korupsi harus memiliki landasan yuridis yang kuat dan alasan-alasan yang dapat dipertanggungjawabkan, karena kalau tidak demikian, maka dalam penegakan hukum pemberantasan tindak pidana korupsi melalui pembatasan hak remisi narapidana, akan berkembang pada pengurangan dan pelanggaran terhadap hak-hak narapidana sebagaimana yang diamanat dalam UU Pemasyarakatan.

Dalam membuat kebijakan hak remisi narapidana kasus korupsi sebagai bentuk penegakan hukum tanpa melanggar hukum, perlu diadakan penyesuaian (harmonisasi) peraturan perundangan yang sudah ada. Penyesuaian dapat dilakukan baik terhadap UU Pemasyarakatan maupun terhadap UU Pemberantasan Tindak Pidana Korupsi dengan mencantumkannya sebagai pidana tambahan, dengan memperhatikan prinsipprinsip hak asasi manusia dalam pembinaan narapidana. Langkah-langkah yang dapat ditempuh antara lain, melalui:

a. Pengkajian faktor penyebab ketidakefektifan penerapan kebijakan hukum pada proses penegakan hukum terhadap pemberian remisi bagi narapidana pelaku tindak pidana korupsi selama ini dengan melibatkan elemen masyarakat;

b. Analisa dan evaluasi yang tajam secara logika formil mengenai filosofi definisi remisi yang mendasarkan pada pemidanaan dengan sistem pemasyarakatan;

Copyright @ C 2016, LITIGASI, p-ISSN: 0853-7100; e-ISSN: 2442-2274 
Available online at: http://ejournal.unpas.ac.id/index.php/litigasi

Litigasi, Vol. 17(1), 2016, 3167-3220

DOI: http://dx.doi.org/10.23969/litigasi.v17i1.48

c. Pengkajian yang cermat dampak dari penerapan kerangka kebijakan hukum pengetatan syarat dan tata cara pemberian remisi terhadap narapidana pelaku tindak pidana korupsi dengan tetap mempertimbangkan hak untuk mendapatkan pengurangan masa hukuman;

d. Pengaturan yang jelas, transparan dan konsisten keterkaitannya dengan peraturan perundang-undangan, antara lain UUD 1945; Kitab UndangUndang Hukum Pidana (KUHP); Kitab Undang-Undang Hukum Acara Pidana (KUHAP); UU Nomor 20 Tahun 2001 jo UU Nomor 31 Tahun 1999 tentang Pemberantasan Tindak Pidana Korupsi; UU tentang Hak Asasi Manusia; $U U$ yang berkaitan dengan tindak pidana tertentu, misalnya UU Narkotika, UU Psikotropika, UU Terorisme; UU Nomor 12 Tahun 2001 tentang Pembentukan Peraturan Perundang-undangan. Kemudian disesuaikan dengan kerangka peraturan remisi yang baru, sehingga tidak tumpang tindih, tidak kontradiktif, namun relevan.

e. Pendekatan yang bersifat akomodatif, realistis, futuristis, dalam penyusunan kerangka kebijakan hukum pemasyarakatan yang baru untuk mendapatkan hasil yang komprehensif atau holistik dengan tujuan pemidanaan;

f. Pengawasan yang ketat dan akuntabel dalam pelaksanaan pemberian remisi bagi narapidana khususnya narapidana pelaku tindak pidana korupsi, dan memastikan bahwa melalui penerapan kebijakan atau peraturan pemberian remisi yang baru akan dapat tercapai ketertiban dalam lembaga pemasyarakatan dan keadilan baik bagi narapidana maupun masyarakat.

g. Jaminan independensi proses penanganan pemberian remisi yang transparan mulai dari proses penilaian sampai dengan proses penerimaannya.

Copyright @ C 2016, LITIGASI, p-ISSN: 0853-7100; e-ISSN: 2442-2274 
Available online at: http://ejournal.unpas.ac.id/index.php/litigasi

Litigasi, Vol. 17(1), 2016, 3167-3220

DOI: http://dx.doi.org/10.23969/litigasi.v17i1.48

\section{SIMPULAN DAN SARAN}

\section{A.Simpulan}

1. Hak remisi narapidana bukan merupakan hak yang bersifat inalienable rights (yang tidak dapat dihapus atau dicabut). Hak remisi merupakan hak-hak yang diberikan oleh hukum (legal rights), yang pemberiannya tidak sertamerta, tetapi ada syarat-syarat dan tata cara yang wajib dipenuhi. Itulah sebabnya, dapat dikatakan bahwa hak memperoleh remisi adalah hak yang terbatas, yakni dibatasi oleh syarat dan tata cara tertentu. Namun, pembatasan syarat dan tata cara tersebut tidak dapat dilakukan secara direktif melalui peraturan pemerintah (PP Nomor 99 Tahun 2012), karena dalam UU Pemasyarakatan, hak remisi adalah hak setiap narapidana tanpa ada pembedaan berdasarkan kualifikasi tindak pidana yang dilakukan.

2. Kebijakan pembatasan hak remisi bagi narapidana kasus korupsi untuk masa yang datang, dapat dilakukan dengan mencantumkan ketentuannya dalam UU Pemasyarakatan.

B. Saran

1. Perlu dilakukan revisi terhadap UU Pemasyarakatan, dengan terlebih dahulu mengadakan langkah-langkah berupa pengkajian dan evaluasi terhadap kebijakan pemberian remisi narapidana kasus korupsi berdasarkan filosofi pemidanaan dengan sistem pemasyarakatan.

2. Dalam pemberian remisi juga perlu dilakukan pengawasan yang ketat dan akuntabel serta adanya jaminan transparansi mulai dari proses penilaian sampai dengan proses penerimaannya untuk menghilangkan pandangan bahwa begitu mudahnya narapidana mendapatkan remisi.

Copyright @ C 2016, LITIGASI, p-ISSN: 0853-7100; e-ISSN: 2442-2274 


\section{DAFTAR PUSTAKA}

Adnan Buyung Nasution, 2011, Demokrasi Konstitusional. Jakarta: PT. Kompas Media Nusantara.

Bryan A. Garner (Editor in Chief), 2004, Black's Law Dictionary, Ninth Edition, West A Thomson Reuters Business, St. Paul, Minn, USA.

Dindin Sudirman, 2007, Reposisi dan Revitalisasi Pemasyarakatan Dalam Sistem Peradilan Pidana Indonesia, Jakarta: BPSDM Depkumham.

Direktorat Jenderal Pemasyarakatan Departemen Kehakiman dan HAM R.I., 2004, 40 Tahun Pemasyarakatan Mengukir Citra Profesionalisme. Jakarta.

Elwi Danil, 2011, Korupsi: Konsep, Tindak Pidana, dan Pemberantasannya, Jakarta: PT. Raja Grafindo Persada.

JAN Remmelink, 2003, Hukum Pidana, Komentar Atas Pasal-Pasal Terpenting dari Kitab Undang-Undang Hukum Pidana Belanda dan Paparannya dalam Kitab Undang-Undang Hukum Pidana Indonesia, Jakarta: Gramedia Pustaka Utama.

Loebby Loqman, 2002, Pidana dan Pemidanaan, Jakarta: Data Com.

Mardjono Reksodiputro, 2007, Bunga Rampai Permasalahan dalam Sistem Peradilan Pidana, Kumpulan Karangan Buku Kelima, Pusat Pelayanan Keadilan dan Pengabdian Hukum (d/h Lembaga Kriminologi), Jakarta: Universitas Indonesia.

Muhammad Yusuf, 2013, Merampas Aset Korupsi; Solusi Pemberantasan Korupsi di Indonesia, Jakarta: Penerbit Kompas.

P.A.F Lamintang dan Theo Lamintang, 2010, Hukum Penintensier Indonesia, Edisi Kedua. Jakarta: Sinar Grafika.

R. Achmad S.Soemadipradja dan Romli Atmasasmita, Tanpa tahun, Sistem Pemasyarakatan di Indonesia, Bandung: BPHN - Departemen Kehakiman, Binacipta.

Romli Atmasasmita, 2004, Korupsi, Good Governance dan Komisi Anti Korupsi di Indonesia, Jakarta: Badan Pembinaan Hukum Nasional, Departemen Kehakiman dan HAM.

Todung Mulya Lubis, 2005, Jalan Panjang Hak Asasi Manusia, Jakarta: PT. Gramedia Pustaka Utama.

JURNAL

Berlian Simarmata, 2011, Pemberian Remisi Terhadap Narapidana Koruptor dan Teroris, Jurnal IImu Hukum MIMBAR HUKUM, Volume 23 Nomor 3.

Harison Citrawan, 2011, Dua Dimensi Remisi, Jurnal IImu Hukum HUMANIS, Volume 2. Tahun VII.

Copyright $\odot$ 2016, LITIGASI, p-ISSN: 0853-7100; e-ISSN: 2442-2274 
Janedjri M. Gaffar, 2013, Peran Putusan Mahkamah Konstitusi dalam Perlindungan Hak Asasi Manusia terkait Penyelenggaraan Pemilu, Jurnal Konstitusi, Volume 10. Nomor 1.

Saldi Isra, 2014, Peran Mahkamah Konstitusi dalam Penguatan Hak Asasi Manusia Di Indonesia, Jurnal Konstitusi, Volume 11. Nomor 3.

Sefriani, 2012, Kewenangan Negara Melakukan Pengurangan Dan Pembatasan Terhadap Hak Sipil Politik, Jurnal Konstitusi, Volume I. Nomor 1.

\section{MAKALAH}

Moh. Mahfud MD., Penegakan Hukum dan Tata Kelola Pemerintahan yang Baik, Disampaikan pada Acara Seminar Nasional Saatnya Hati Nurani Bicara, yang diselenggarakan oleh DPP Partai HANURA, Jakarta: tanggal 8 Januari 2009.

Nyoman Serikat Putra Jaya, Remisi dan Pembebasan Bersyarat dalam Perspektif Tujuan Pemidanaan dan Kebijakan Hukum Pidana, Disampaikan pada Focus Group Discussion "Moratorium Remisi sebagai Akselerator Pemberantasan Korupsi di Indonesia" yang diselenggarakan Fakultas Hukum Undip Semarang, Selasa 15 November 2011.

Romli Atmasasmita, Perspektif Pengadilan Korupsi di Indonesia, Disampaikan Dalam Seminar tentang Pembentukan Pengadilan Korupsi, yang diselenggarakan oleh KHN dan BPHN, Jakarta: 30 Juli 2002.

\section{MEDIA MASSA}

Romli Atmasasmita, Kemerdekaan Terpidana, Koran Sindo 3 November 2011.

Saldi Isra, Memudarnya Imaji Anti Korupsi, Harian Kompas 19 Maret 2015.

\section{PERATURAN PERUNDANGAN}

Undang-Undang Dasar Republik Indonesia Tahun 1945

Ketetapan Majelis Permusyawaratan Rakyat Republik Indonesia Nomor XVII/MPR/1998 tentang Hak Asasi Manusia

Undang-Undang Republik Indonesia Nomor 12 Tahun 1995 tentang Pemasyarakatan.

Undang-Undang Republik Indonesia Nomor 39 Tahun 1999 tentang Hak Asasi Manusia 
Undang-Undang Republik Indonesia Nomor 12 Tahun 2005 tentang Pengesahan International Covenant On Civil And Political Rights (Kovenan Internasional tentang Hak-Hak Sipil dan Politik).

Undang-Undang Republik Indonesia Nomor 7 Tahun 2006 tentang Pengesahan United Natlons Convention Against Corruption, 2003 (Konvensi Perserikatan Bangsa-Bangsa Anti Korupsi, 2003).

Peraturan Pemerintah Nomor 32 Tahun 1999 tentang Syarat dan Tata Cara Pelaksanaan Hak Warga Binaan Pemasyarakatan.

Peraturan Pemerintah Nomor 28 Tahun 2006 tentang Perubahan Atas Peraturan Pemerintah Nomor 32 Tahun 1999 tentang Syarat dan Tata Cara Pelaksanaan Hak Warga Binaan Pemasyarakatan.

Peraturan Pemerintah Nomor 99 Tahun 2012 tentang Perubahan Kedua Atas Peraturan Pemerintah Nomor 32 Tahun 1999 tentang Syarat dan Tata Cara Pelaksanaan Hak Warga Binaan Pemasyarakatan.

Keputusan Presiden Nomor 174 Tahun 1999 tentang Remisi

Putusan Mahkamah Konstitusi Republik Indonesia Nomor 022/PUU-III/2005 tentang Pengujian Undang-Undang Nomor 12 Tahun 1995 tentang Pemasyarakatan.

Peraturan Menteri Hukum dan Hak Asasi Manusia Republik Indonesia Nomor M.Hh01.Pk.02.02 Tahun 2010 Tentang Remisi Susulan.

Peraturan Menteri Hukum dan Hak Asasi Manusia Republik Indonesia Nomor 6 Tahun 2013 tentang Tata Tertib Lembaga Pemasyarakatan dan Rumah Tahanan Negara, Berita Negara Republik Indonesia Tahun 2013 Nomor 356.

Peraturan Menteri Hukum dan Hak Asasi Manusia Republik Indonesia Nomor 21 Tahun 2013 tentang Syarat dan Tata Cara Pemberian Remisi, Asimilasi, Cuti Mengunjungi Keluarga, Pembebasan Bersyarat, Cuti Menjelang Benas dan Cuti Bersyarat.

\section{LAIN-LAIN:}

Forum Keadilan, No. 12 Tahun XXIII / 29 September - 05 Oktober 2014, Remisi Anggodo Kembali Bikin Heboh, Jakarta.

Mata Najwa, Enaknya Jadi Koruptor, ditayangkan di Metro TV, Rabu 26 November 2014, pukul: 20.00 WIB.

Sambutan Menteri Hukum dan HAK Asasi Manusia Republik Indonesia, Disampaikan Dalam Upacara Pemberian Remisi Kepada Warga Binaan Pemasyarakatan, Pada Peringatan Hari Ulang Tahun Proklamsi Kemerdekaan RI Ke 63, Jakarta: 17 Agustus 2008.

Copyright $\odot$ 2016, LITIGASI, p-ISSN: 0853-7100; e-ISSN: 2442-2274 